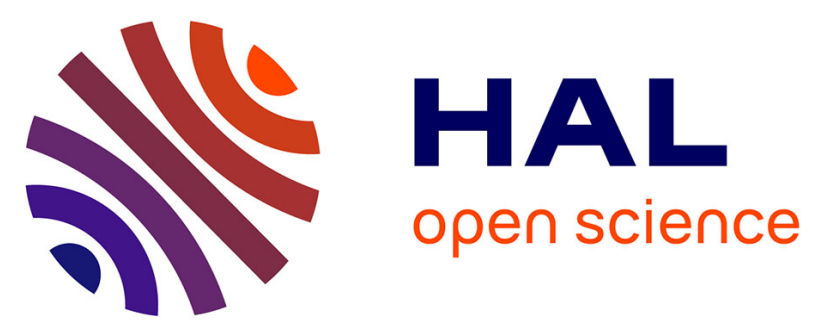

\title{
Volcanic plume aging during passive degassing and low eruptive events of Etna and Stromboli volcanoes
}

\author{
Joris Pianezze, Pierre Tulet, Brice Foucart, Maud Leriche, Marco Liuzzo, \\ Guiseppe Salerno, Aurélie Colomb, Evelyn Freney, Karine Sellegri
}

\section{To cite this version:}

Joris Pianezze, Pierre Tulet, Brice Foucart, Maud Leriche, Marco Liuzzo, et al.. Volcanic plume aging during passive degassing and low eruptive events of Etna and Stromboli volcanoes. Journal of Geophysical Research: Atmospheres, 2019, 124 (21), pp.11389-11405. 10.1029/2019JD031122 . hal-02349783

\section{HAL Id: hal-02349783 \\ https://hal.science/hal-02349783}

Submitted on 23 Aug 2021

HAL is a multi-disciplinary open access archive for the deposit and dissemination of scientific research documents, whether they are published or not. The documents may come from teaching and research institutions in France or abroad, or from public or private research centers.
L'archive ouverte pluridisciplinaire HAL, est destinée au dépôt et à la diffusion de documents scientifiques de niveau recherche, publiés ou non, émanant des établissements d'enseignement et de recherche français ou étrangers, des laboratoires publics ou privés. 


\title{
Volcanic plume aging during passive degassing and low eruptive events of Etna and Stromboli volcanoes.
}

\author{
J. Pianezze , P. Tulet ${ }^{1}$, B. Foucart ${ }^{1}$, M. Leriche ${ }^{2,3}$, M. Liuzzo ${ }^{4}$, G. Salerno $^{5}$, A. \\ Colomb $^{6}$, E. Freney ${ }^{6}$, K. Sellegri ${ }^{6}$ \\ Laboratoire de l'Atmosphère et des Cyclones (LACy / UMR 8105, CNRS, Université de la Réunion, \\ Météo-France), Saint-Denis, La Réunion, France \\ Laboratoire d'Aérologie (LA / UMR 5560, CNRS, Université Paul Sabatier), Toulouse, France \\ de et la Simulation du Climat à l'Échelle Régionale (ESCER, Université du Québec à \\ Montréal), Montréal, Canada \\ Istituto Nazionale di Geofisica e Vulcanologia, Sezione di Palermo, Palermo, Italy \\ Istituto Nazionale di Geofisica e Vulcanologia, Osservatorio Etneo, Sezione di Catania, Catania, Italy \\ Laboratoire de Météorologie Physique (LaMP / UMR 6016, CNRS, Université Blaise Pascal), Aubière, \\ France
}

\section{Key Points:}

- Meso-NH/SurfEx successfully simulates Etna and Stromboli volcanic plumes aging processes ;

- Model evaluation through comparison with observations ;

- Volcanic plumes from passive degassing and low eruptive events significantly impact atmospheric CCN concentrations. 


\title{
Accepted Article
}

\begin{abstract}
Volcanic gases and aerosols emissions from passive degassing or low eruptive events are now included in most climate models despite large uncertainties still exist about their injection height and their temporal and spatial variability. The aim of this study is to quantify the evolution of the gas and aerosols inside volcanic plumes with high kilometric resolution simulations. With online chemistry and aerosols, these simulations are carried out together with in-situ measurements of aerosol and gas-phase properties to assess the impact of Etna and Stromboli volcanic plumes produced by passive degassing and regular Strombolian activity, respectively. Comparison between simulation and observations show that the simulation reproduces the main characteristics of the volcanic plume evolution, and confirms that volcanic plumes produced by passive degassing or low eruptive events have a strong impact on cloud condensation nuclei $(\mathrm{CCN})$ formation increasing the number of $\mathrm{CCN}$ by a factor of 5 . It was also shown that depending on the plume location, the aerosols will act as CCN at different distance from the vent. In the marine atmospheric boundary layer, the aerosols will act as CCN at proximity to the vent (less than $50 \mathrm{~km}$ ) because of strong condensation sink inhibiting nucleation. In comparison, in the free troposphere, aerosols will act as CCN far from the vent, at more than $200 \mathrm{~km}$. To the best of our knowledge, this study using in-situ measurements as well as sub-kilometric simulations is unique.
\end{abstract}

\section{Introduction}

Active volcanoes are one of the most dangerous natural hazard on Earth (e.g, Loughlin et al. (2015)). In addition to lava flows and volcanic bombs, volcanoes can emit a large amountlarge amounts of volatile species in the atmosphere, from both eruptive or passive degassing events (Oppenheimer et al., 2014; Mather, 2015).

Volcanic plumes are composed of several gasesgaseous species (water vapor $\left(\mathrm{H}_{2} \mathrm{O}\right)$, sulfur dioxide $\left(\mathrm{SO}_{2}\right)$, carbon dioxide $\left(\mathrm{CO}_{2}\right)$, hydrogen sulfide $\left(\mathrm{H}_{2} \mathrm{~S}\right)$, hydrogen chloride $(\mathrm{HCl}), \ldots)$ and aerosols (Allard et al., 2000). Since sulfur dioxide is one of the main precursor gasgases for the new particlesparticle formation (Weber et al., 1995, 1999; Kulmala et al., 2000; Kerminen et al., 2018), volcanic plumes can be composed of secondary aerosolsare also considered as an important source of nanometric sizesd particles (Boulon et al., 2011; Sahyoun et al., 2019). They can additionally contain primary aerosols whose emission mechanism is not yet well understood (Mather et al., 2006; Roberts et al., 2018).

Depending on their injection height in the atmosphere, these volcanic gases and aerosols can have different impacts. For strong eruptive events, volcanic plumes can reach stratospheric levels where aerosols scatter and absorb solar radiation on large scales, inducing a net global cooling via the direct aerosol effect (Stenchikov et al., 1998; Robock, 2000). It was shown that large volcanic plumes can cause a decrease of the mean global surface temperature by tenth of degree over several years following eruptions (Robock and Oppenheimer (2003) and reference therein). For low eruptive or passive degassing events, volcanic plumes are mostly confined in the troposphere and their impacts on aerosol properties and on the regional radiation budget are still largely unknown (Mather, 2015; Sellitto et al., 2017). Depending on itstheir size and chemical composition, these aerosols can modify the regional radiation budget by scattering and absorbing solar radiation and therefore have an impact on local meteorology (Mather, 2015) and climate (Haywood \& Boucher, 2000). They can also interact with meteorological processes as they can act as a cloud condensation nuclei (CCN) (Mather, 2015) or Ice Nuclei (IN) (Hoyle et al., 2011) and therefore modify the local radiative budget via the indirect aerosol effect. Due to deposition of volcanic acid gases and aerosols, volcanic plumesDeposition of acidic gases and aerosols can also affect terrestrial and aquatic environments (Delmelle, 2003). Volcanic emissions are also known to cause significant impacts on air traffic transport and can additionally cause damage to the airframe and/or engine components and therefore 


\section{Accepted Article}

perturb aircraft transport (Schmidt et al., 2014). Finally, nanometric size aerosols are dangerous for human health, as they can penetrate deep into the lungs and even into the bloodstream (U.S. Environmental Protection Agency ; https://www.epa.gov). It is therefore essential to prevent disruptions tropospheric volcanic plumes may cause.It is therefore essential to understand the evolution of gases and aerosols in the volcanic plume in order to better predict and therefore anticipate the associated risks.

The high spatial and temporal variability of the tropospheric volcanic plumes and the extreme condition encountered within the plumes (high temperatures, high gas-phase concentrations, ...) make in-situ observations difficult. Recent satellitebased observations open a new era in the observation of volcanic plumes (Queier et al., 2019; Theys et al., 2019). Indeed,, where chemical constituents, especially $\mathrm{SO}_{2}$, can be measured thanks to passive ultraviolet, infrared and microwave sensors on the satellites (see review of Carn et al. (2016)). However, the daily total column SO concentration are only measured by satellites once a day (mostly polar orbiting satelittes) making the study of the evolution of volcanic plumes complicated.

At present, research efforts were mainly focused on the impact of large explosive volcanic eruptions on climate through numerical global simulations. They are summarized in the Intergovernmental Panel of Climate Change reports (Intergovernmental Panel on Climate Change, 2014). In these studies, climatic impacts of volcanic eruptions are simulated through the formation of sulfuric acid aerosols from sulfur dioxide oxidation. These impacts are (1) an enhancement of the aerosol optical depth modifying the absorption and scattering radiation effect (Voldoire et al., 2013; Randles et al., 2013; Kravitz et al., 2011; Berthet et al., 2017; Khodri et al., 2017) and (2) an increase in the concentration of cloud droplets of small radius and hence cloud reflectivity (Quaas \& Boucher, 2005). These modelling studies used bulk aerosol schemes and/or assumed aerosols size distributions creating inconsistencies between chemistry, dynamic and physico-chemical properties of aerosols. Indeed, aerosol properties evolve based on dry and wet deposition, coagulation, condensation, nucleation, transport and diffusion processes making their impact on radiation and/or cloud variable in space and time. It is thus essential to represent the evolution of aerosol distribution online with chemistry and dynamic modelling. Despite the fact that they concern between 30 and $70 \%$ of the total $\mathrm{SO}_{2}$ annual emissions (Halmer et al., 2002; Mather et al., 2003), only a few recent studies exist on the impact of volcanic plumes resulting from passive degassing or low intensity eruptive events on the radiative budget on global scale (Schmidt et al., 2012; Mather, 2015). Studying these volcanic plumes requires solving the atmospheric structures present in the free troposphere and in the atmospheric boundary layer, not precisely achievable by current climate models that parametrized the boundary layer subgrid processes. Thanks to the increase of computational resources, regional modelling studies at high km-kilometric resolution with dynamic, chemistry and aerosol interactions are reachablepossible, even if simulation length has to be limited to few days and on regional domains. To the best of our knowledge, no studies exist on modelling tropospheric volcanic aerosols aging at the km-resolution. In this context, this article aims to increase our knowledge on our ability to understand the main processes taking place within volcanic plumes and their potential impacts with km-resolution simulations.

This study focuses on the evolution of sulfur dioxide and aerosol size distribution in the Etna and Stromboli volcanic plumes on 15 and 16during two cases study periods in June 2016, where a field campaign was conducted to observe the volcanic plume constituents (gases and aerosols). Note that Etna and Stromboli volcanoes are two of the most active volcanoes in Europe. At that time, Etna was in passive degassing eventphase whereas Stromboli was in a normal phase of strombolian activity corresponding to a low intensity eruptive event. The main objectives of this paper isare (1) to reproduce the observed spatial and temporal evolution of the volcanic plumes produced by Etna and Stromboli volcanoes using km-resolution simulations, (2) to quantify the processes involved in the aerosol size distribution evolution inside 


\section{Accepted Article}

the volcanic plumes and (3) to quantify the ability of the aerosols contained in the volcanic plumes to act as CCN. and their potential effect on local meteorology and even climate.

This paper is divided into five sections: Section 2 presents the campaign and the data available. The modelling framework is described in Section 3. Section 4 presents the structure of the simulated volcanic plumes and their evaluation with the available data. The volcanic plumes agingAging of the volcanic plumes and their effects on CCN are presented in Section 5. Finally, the discussion and conclusions are given in Section 6 .

\section{STRAP campaign around Etna and Stromboli, 15 and 16 June 2016}

In order to understand the processes involved in the atmospheric volcanic source terms, i.e. mass discharge rateemission rates and in the composition of the gas and particles mixture erupted from the vent, two STRAP campaigns were conducted (The acronym STRAP means "Synergie Transdisciplinaire pour répondre aux Aléas liés aux Panaches volcaniques" in french and can be translated in english to "Trans-disciplinary collaboration to investigate volcano plumes risks"). One of them was made around Piton de la Fournaise, in La Réunion (Tulet et al., 2017) and another around Etna and Stromboli volcanoes, in Italy (Sahyoun et al. (2019), this study).

This study focuses on 15 and 16 June 2016the latter campaign during which Etna volcano was in a phase of passive degassing and Stromboli volcano in a normal phase of strombolian activity, which are typical inter-eruptive conditions for both volcanoes. During those days, the volcanic plumes were limited to the $4 \mathrm{kmthe}$ volcanic plumes height remained below $4 \mathrm{~km}$ above the sea level, in the marine atmospheric boundary layer (MABL) for the Stromboli plumes and in the free troposphere (FT) for the Etna plumes.

These two volcanoes are monitored throughout the year by the Istituto di Geofisica e Vulcanologia in Italy, givenproviding access to daily emissions data of the main emitted gases : $\mathrm{H}_{2} \mathrm{O}, \mathrm{CO}_{2}$ and $\mathrm{SO}_{2}$. In addition to this permanent observation, four flights were conducted during the STRAP campaign, using the French research aircraft SAFIRE - ATR42 equiped with a range of instrumentation for the study of aerosols and gas-phase properties (The acronym SAFIRE means "Service des Avions Franais Instrumentés pour la Recherche en Environnement" in french and can be translated in english to "the French facility for airborne research"). Full details of all instruments installed on the aircraft are provided by Sahyoun et al. (2019), however for the purpose of this work we will provide a short overview of the instruments that are used in this study. The flights trajectory and the measured $\mathrm{SO}_{2}$ concentration are presented in Fig. 1. Two flights were located around Etna and two others around Stromboli. Flight tracks involved first doing a vertical sounding to locate the height of the volcanic plume, this was then followed by a number of transects crossing over the plume for distances up to $100 \mathrm{~km}$. Further transects involved flying along the center of the plume.

The main data sets related to the gases and aerosols properties used in this work are listed Tab. 1. The $\mathrm{SO}_{2}$ concentration is measured by ultra-violet fluorescence SO analyser (Teledyne API). The number of aerosols are given by two condensation particle counters (CPCs) : one measures aerosol concentration of particles with a cut-off diameter higher than $2.5 \mathrm{~nm}$ (Kupc et al., 2013) and another with cut-off diameter higher than $10 \mathrm{~nm}$ (Weigel et al., 2009). The size distribution is given by a custom made airborne Scanning Mobility Particle Sizer spectrometer (SMPS) from 20 to $500390 \mathrm{~nm}$ having more than 100 channels and by a GRIMM Optical Particle Counter (OPC) from 0.25 to $2.5 \mu \mathrm{m}$ having 30 channels. It should be noted that the aerosol inlet installed on the aircraft has $50 \%$ sampling efficiency for $5 \mu \mathrm{m}$ aerosol 


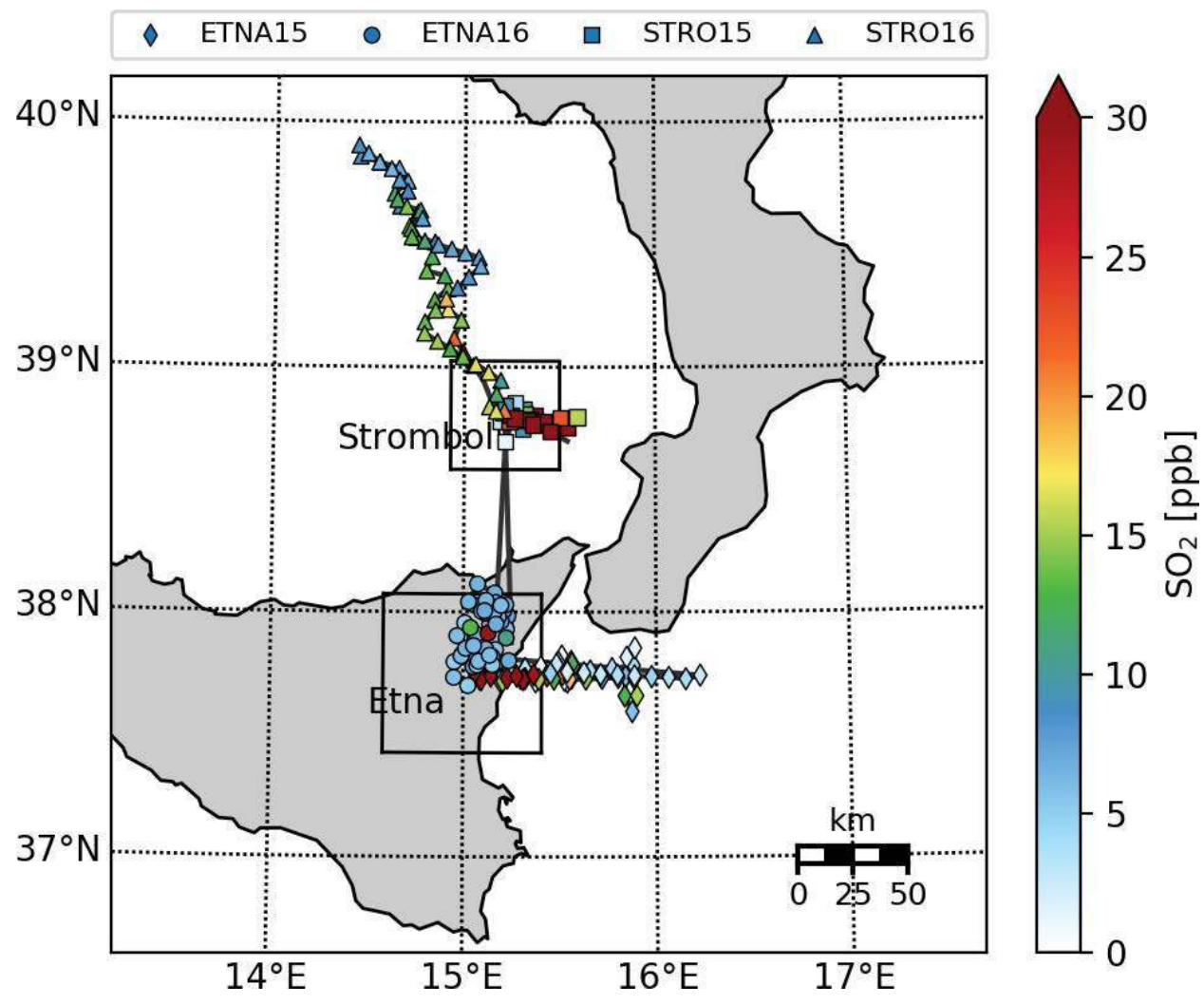

Figure 1. Track of the four SAFIRE-ATR42 flights : ETNA15 corresponds to 15 June 2016 flight around Etna (diamonds), ETNA16 to 16 June 2016 flight around Etna (dots), STRO15 to 15 June 2016 flight around Stromboli (squares) and STRO16 to 16 June 2016 flight around Stromboli (triangles). $\mathrm{SO}_{2}$ concentration measured airborne are in colors [ppb]. Black lines correspond to the location of the two nested domains at $500 \mathrm{~m}$ horizontal resolution (Section 3)

particles (Freney et al., 2014), so it is unlikely that particles much larger than this size were sampled.

Table 1. Data available around Etna and Stromboli volcanic plumes during 15 and 16 June 2016. $D$ is for particle diameter.

\begin{tabular}{|c|c|c|c|c|}
\hline Data & Instrument & Location & Sampling period & Unit \\
\hline Emissions mass rate $\left(\mathrm{H}_{2} \mathrm{O}, \mathrm{CO}_{2}, \mathrm{SO}_{2}\right)$ & analyser & vent & Daily & $\mathrm{kg} \mathrm{s}^{-1}$ \\
\hline $\mathrm{SO}$ concentration & analyser & flights & $1-\mathrm{s}$ & $\mathrm{ppb}$ \\
\hline Particle number concentration $\left(D_{p}>2.5 \mathrm{~nm}\right)$ & $\mathrm{CPC}$ & flights & $1-\mathrm{s}$ & $\mathrm{cm}^{-3}$ \\
\hline Particle number concentration $\left(D_{p}>10 \mathrm{~nm}\right)$ & $\mathrm{CPC}$ & flights & $1-\mathrm{s}$ & $\mathrm{cm}^{-3}$ \\
\hline Aerosol size distribution ( 100 channels from $D_{p}=20 \mathrm{~nm}$ to $1 \mu \mathrm{m}$ ) & SMPS & flights & $84-\mathrm{s}$ & $\mathrm{cm}^{-3}$ \\
\hline Aerosol size distribution ( 30 channels from $D_{p}=0.25 \mu \mathrm{m}$ to $32 \mu \mathrm{m}$ ) & $\mathrm{OPC}$ & flights & $6-\mathrm{s}$ & $\mathrm{cm}^{-3}$ \\
\hline
\end{tabular}

\section{Modelling framework}

Meso-NH is used to simulate the atmospheric processes involved in the Etna and Stromboli volcanic plumes evolution.http://mesonh.aero.obs-m ip.fr/mesonh530). It is a non-hydrostatic, anelastic and mesoscale atmospheric model (Lac et al., 2018). 


\section{Accepted Article}

Thanks to its large set of parametrizationsfully coupled framework (small scale dynamic, online chemistry and aerosols, radiative transfer, ...), Meso-NH is able to represent atmospheric motions from the vent of the volcanoes up to hundred of $\mathrm{km}$ away from it and is able to simulate the atmospheric processes implicated in the volcanic plume evolution (Lac et al., 2018). Furthermore, Meso-NH has been successfully used to study volcanic plumes transport over South West Indian Ocean (Tulet \& Villeneuve, 2011) and La Reunion Island (Durand et al., 2014).

The grid configuration, physical parameterization, dynamical, aerosol and chemical schemes and also the surface fluxes and emissions used in this study are described in the following Sections.

\subsection{Grid configuration}

The horizontal grid configuration contains three domains in two-way interactions: one domain at $2 \mathrm{~km}$ horizontal resolution and two others at $500 \mathrm{~m}$ horizontal resolution zoomed on both volcanoes : Etna and Stromboli (Fig. 1). The vertical grid wasis common to both modelsdomains and hadhas 70 stretched levels. The first level wasis at $10 \mathrm{~m}$ above the surface. The top of the domain reaches $22 \mathrm{~km}$ with a maximum vertical grid spacing of $1 \mathrm{~km}$. The two nested domains at $500 \mathrm{~m}$ horizontal resolution and the $10 \mathrm{~m}$ vertical grid spacing above the surface are used to better represent the boundary layer processes around the volcano vents and hence the injection height of the volcanic plumes. The orography used is based on Shuttle Radar Topography Mission database at $250 \mathrm{~m}$ (Farr et al., 2007) (https://www2.jpl.nasa.gov/srtm/).

\subsection{Physical parametrization and dynamic}

The radiative scheme used in this study wasis the one used at the European Centre for Medium-Range Weather Forecasts (ECMWF ; Gregory et al. (2010)) including the Rapid Radiative Transfer Model (RRTM) parameterization for longwave radiation (Mlawer et al., 1997). The microphysics scheme wasis a single-moment bulk mixedphase scheme that predicts the mixing ratio of five microphysical species: cloud water, rain, cloud ice, snow and graupel (Pinty \& Jabouille, 1998). A shallow convection parameterization based on mass-flux calculations (Bechtold et al., 2001) wasis used in the large domain. The turbulence parameterization wasis based on a 1.5-order closure (Cuxart et al., 2000). To have more mixing and diffusion of scalar variables in the boundary layer, the three-dimensional mixing length of Deardorff (1980) is used. Associated with an explicit Runge-Kutta temporal scheme, momentum variables wereare advected with a fifth order weighted essentially nonoscillatory scheme (Lunet et al., 2017). Scalar and other meteorological variables (included chemistry and aerosol variables) wereare advected with a monotonic Piecewise Parabolic Method to ensure positive values (Colella \& Woodward, 1984) with forward-in-time temporal scheme (Lunet et al., 2017). The dynamical time step wasis $4 \mathrm{~s}$ for the domain at $2 \mathrm{~km}$ and $2 \mathrm{~s}$ for others $4 \mathrm{~s}$ in the host domain and $2 \mathrm{~s}$ in the nested domains.

The initial and boundary conditions for meteorology wereare provided by the ECMWF operational high-resolution analysis with a horizontal and temporal resolution of $0.125(\approx 13 \mathrm{~km})$ and $6 \mathrm{~h}$, respectively.

\subsection{Aerosol scheme}

ORILAM (ORganic Inorganic Lognormal Aerosol Model ; Tulet (2005)) is used to simulate aerosol processes, such as nucleation, coagulation, condensation, dry deposition and sedimentation. Since anticyclonic and rainless conditions were present on the days of this study, no wet deposition scheme is activated. ORILAM is based on the modal aerosol dynamics modelling representing the aerosol size distribution as an assemblage of two distinct populations of aerosols called modes (Whitby \& McMurry, 


\section{Accepted Article}

1997). As described in Schumann (2012), one mode combines nucleation and Aitken modes into a single Aitken mode (iait hereafter). This mode represents particles with diameters lower than $50 \mathrm{~nm}$. The other mode is called the accumulation mode (jacc hereafter) and represent aerosols with diameters between 50 and $300 \mathrm{~nm}$ of diameter. No third mode is available in ORILAM, therefore no coarse mode is used in this study. Based on calculations combining SMPS and OPC measurements made in the aircraft (not shown here), the errors due to the absence of a coarse mode are estimated on average to (i) less than $0.6 \%$ for the total aerosol number and (ii) less than $10 \%$ for the condensation processes. An error on the intermodal coagulation processes is also expected but is difficult to evaluate precisely. Including a coarse mode in ORILAM will be performed as part of future studies. The size distribution of eachthe two modes is modelled by a lognormal distribution functions, defined by a particle number concentration $(N)$, a median diameter $\left(D_{p}\right)$ and a standard deviation $\left(\sigma_{p}\right)$.

New homogeneous binary nucleation parametrization of Maattanen et al. (2018) has been implemented in Meso-NH and is used in this study. This parametrization is valid for a large range of sulfuric acid concentrations, ideal for studying volcanic plumes. Following a sensitivity study not shown here, the median diameter and standard deviation of the aerosol size distribution of the nucleated particle is taken to be $25 \mathrm{~nm}$ and 1.2, respectively. The condensation parametrization is treated asfollowing Binkowski (2003) and is adapted for the treatment of the 6th moment. Sedimentation, dry deposition and coagulation parameterizations used in this study are based on the initial work of Tulet (2005).

Initial parameters for the two lognormal modes $\left(N, D_{p}\right.$ and $\left.\sigma_{p}\right)$ wereare obtained from SMPS measurements acquired during research flights. The initial parameters for the two modes $\mathrm{i}$ and $\mathrm{j}$ are obtained when flight werewhere outside the volcanic plumes (considered as background distributions) and are equal to $D_{p}=40 \mathrm{~nm}$ and $\sigma_{p}=1.2$ for the Aitken mode i and to $D_{p}=60 \mathrm{~nm}$ and $\sigma_{p}=1.8$ for the accumulation modej. In this study and for numerical stability constraint, the geometric standard deviation of the two modes are kept constant during the simulation.

The initial and boundary conditions for aerosols concentration wereare taken from MOZART-4 (Model for OZone And Related chemical Tracers, version 4) (Emmons et al., 2010) driven by meteorology from NCEP/NCAR reanalysis meteorological fields with a horizontal and temporal resolution of $0.5^{\circ}(\approx 50 \mathrm{~km})$ and $6 \mathrm{~h}$, respectively. In the two days of simulation, meteorological conditions bring dust aerosols from north Africa. Although, they can have effect on the condensation sink and therefore indirectly on the nucleation processes, they are only imposed as background aerosols initialized by MOZART-4. Their emissions are not taken into account explicitly.

\subsection{Gas chemistry}

The gas phase chemical mechanism used in this study is an updated version of the original ReLACS (Regional Lumped Atmospheric Chemical Scheme ; Crassier et al. (2000)). Four prognostic gaseous species wereare added for the purposes of the aqueous chemistry application (ammonia, sulphuric acid, hydroxyl radical and formic acid), leading to 41 prognostic species in the gas phase (Leriche et al., 2013). In this configuration, sulfuric acid $\left(\mathrm{H}_{2} \mathrm{SO}_{4}\right)$ available for nucleation and/or condensation on existing particles is directly formed by reaction between the hydroxyl radical $(\mathrm{OH})$ and $\mathrm{SO}$ and is therefore highly dependent on sunrise. The photolytic rates are calculated using the TUV radiation model (Tropospheric Ultraviolet and Visible radiation model ; Madronich and Flocke (1999)). The version 5.3 has been implemented recently in Meso-NH and is used in this study. The chemistry time step is equal to $1 \mathrm{~s}$ for both domains.

As for aerosols, the initial and boundary conditions for gaseous chemical species wereare taken from the same MOZART-4 data. 


\subsection{Surface fluxes and emissions}

The surface-atmosphere interactions are grouped on a surface modelling platform, called SurfEx (Surface Externalisée in French ; Voldoire et al. (2017)). The SurfEx platform used in this study includeds the ISBA model (Interaction Soil-BiosphereAtmosphere ; Noilhan and Planton (1989)), a land surface model to represent biosphere fluxes, the TEB model (Town Energy Balance ; Masson (2000)), to represent town fluxes, and the COARE parameterization of sea surface fluxes (Coupled OceanAtmosphere Response Experiment ; Fairall et al. (2003)). A sensible heat flux of 1000 $\mathrm{W} \mathrm{m}$ is imposed at the volcano's vents to better represent the injection's height of the two volcanic plumes in comparison with observations.

Surface emissions of aerosol and chemical compounds wereare taken from the ECCAD (Emissions of atmospheric Compounds Compilation of Ancillary Data, http://ecc ad.aeris-data.fr/), which compiles the main emissions datasets available for the community. Anthropogenic emissions are provided by the monthly MACCity emissions dataset (MACC/CityZEN EU projects) (Lamarque et al., 2010) with a horizontal grid resolution of $0.5^{\circ}(\approx 50 \mathrm{~km})$. To represent biomass burning emissions, the monthly GFED3 (Global Fire Emissions Database, version 3; van der Werf et al. (2010) database was used with a horizontal resolution of $0.5^{\circ}(\approx 50 \mathrm{~km})$. The biogenic emissions wereare modelled by MEGAN (Model of Emissions of Gases and Aerosols from Nature; Guenther et al. (2012)) and was recently implemented in ISBA. In addition to these emissions, a $\mathrm{SO}_{2}$ and latent heat fluxes emissions wasare imposed at the volcano's vent based on daily $\mathrm{SO}_{2}$ emissions : 25 to $38 \mathrm{~kg}$ s 2160 to $3283 \mathrm{kt}^{\mathrm{day}}{ }^{-1}$ for Etna and 2 to $4 \mathrm{~kg}$ s172 to $345 \mathrm{kt} \mathrm{day}^{-1}$ for Stromboli, for 15 to 16 June 2016, respectively. At that time there wereare no $\mathrm{SO}_{2}$ emissions measurements at higher temporal resolutionfrequency.

\section{Description and evaluation of the simulation with available obser- vations}

\subsection{Volcanic plumes structure}

The spatial distribution of the simulated volcanic plumes and the aircraft flights position are shown in Fig. 2. The volcanic plumes location are represented by the simulated SO (isoline at $4 \mathrm{ppb}$ ) at a representative time of the flights, i.e. 15 June 2016 at 15 UTC for ETNA15 and STRO15 flights and 16 June 2016 at 8 UTC for ETNA16 and STRO16 flights.

Due to a rotation of the prevailing wind from East to the North-East during these two days, volcanic plumes present different structures. For 15 June at 15 UTC (Fig. 2a), Etna and Stromboli plumes are well separated. Etna plume is advected to the South East of the vent in the FT, while Stromboli plume is advected in both East and West direction due to vertical wind shear and is located in the MABL. Due to the turbulent mixing of the MABL, simulated $\mathrm{SO}_{2}$ is more diluted in Stromboli plume than in the Etna plume. For 16 June at 8 UTC (Fig. 2b), a part of the Etna and Stromboli plumes are mixed with each other at proximity ofabove the Stromboli volcano, at approximately $800 \mathrm{~m}$ above sea level. Close to the emission, Etna plume propagates to the North East. When lowering due to wind subsidencesubsiding, the plume transport rotates in the direction of the Stromboli, which is advected to the North West. Both plumes are located in the MABL inducing a strong dispersion of the simulated $\mathrm{SO}_{2}$. The simulated $\mathrm{SO}_{2}$ is colocated with the position of the four flights (white dots in Fig. 2) in terms of horizontal and vertical positions. Evaluation of the simulated chemical and aerosols fields in the aircraft will be made in the next sections.

Among the four flights,ETNA15 and STRO16 flights covered the longest distances (more than $200 \mathrm{~km}$ from the volcanoes vent) and are interesting for studying 


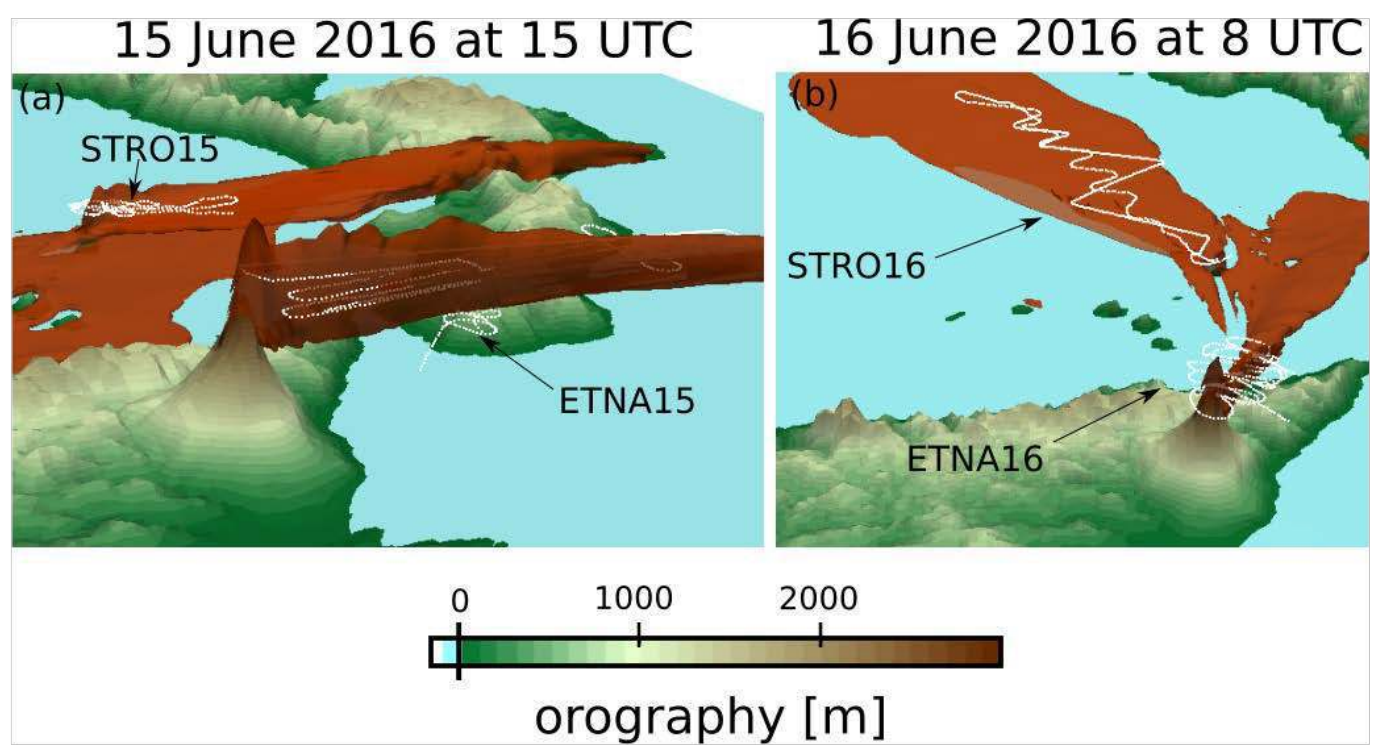

Figure 2. Spatial distribution of the simulated $\mathrm{SO}_{2}$ at 4 ppb at (a) 15 June 2016 at 15 UTC and (b) 16 June 2016 at 8 UTC (domain at $2 \mathrm{~km}$ resolution). Flights trajectories are represented by white dots.

volcanic plumes aging processes. In the rest of this article, weFor this reason, the remaining discussion will focus on these two flights.

\subsection{Sulfur dioxide concentration}

For 15 June 2016 at 15 UTC (Fig. 3a,c), vertical oscillations on simulated $\mathrm{SO}_{2}$ of Etna plume are visible close to the vent. This is a result of the presence of orographic waves reinforced by a stable atmospheric boundary layer at that time. Despite these orographic waves, the Etna plume, injected at $4 \mathrm{~km}$, is advected to more than 200 $\mathrm{km}$ to the South East of the vent, at approximately $3300 \mathrm{~m}$ above sea level (in the FT)while it was injected at about $4 \mathrm{~km}$. The width and thickness of the plume are roughlyapproximately equal to $2 \mathrm{~km}$ and $500 \mathrm{~m}$, respectively. $\mathrm{SO}_{2}$ concentration goesdecreases from more thanapproximately $210 \mathrm{ppb}$ close to the vent, which is on the same ordre of magnitude as that observed by (Roberts et al., 2018) during another passive degassing events of Etna on October 2013, to roughly $10 \mathrm{ppb}$ at $150 \mathrm{kmfrom}$ it, corresponding approximately to an horizontal dilution factorloss rate of about 1.3 ppb km . For 16 June 2016 at 8 UTC (Fig. 3b,d), Stromboli plume is located in the MABL and is advected to the North West at a constant height $(\approx 150 \mathrm{~m}$ a.s.l.). Simulated SO varies from $200 \mathrm{ppb}$ close to the vent to $10 \mathrm{ppb}$ at $75 \mathrm{~km}$ distance

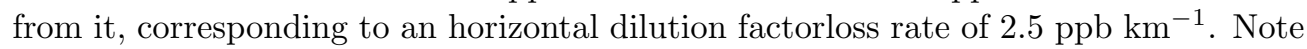
that this dilution factorloss rate is more important than Etna plume because of the turbulent mixing in the MABL and the water vapor content which is more important in the MABL $\left(10 \mathrm{~g} \mathrm{~kg}^{-1}\right)$ than in the FT $\left(4 \mathrm{~g} \mathrm{~kg}^{-1}\right)$. 
ETNA15 : 201606151500 alt. $=3.3 \mathrm{~km}$
STRO16 : 201606160800

alt. $=0.15 \mathrm{~km}$
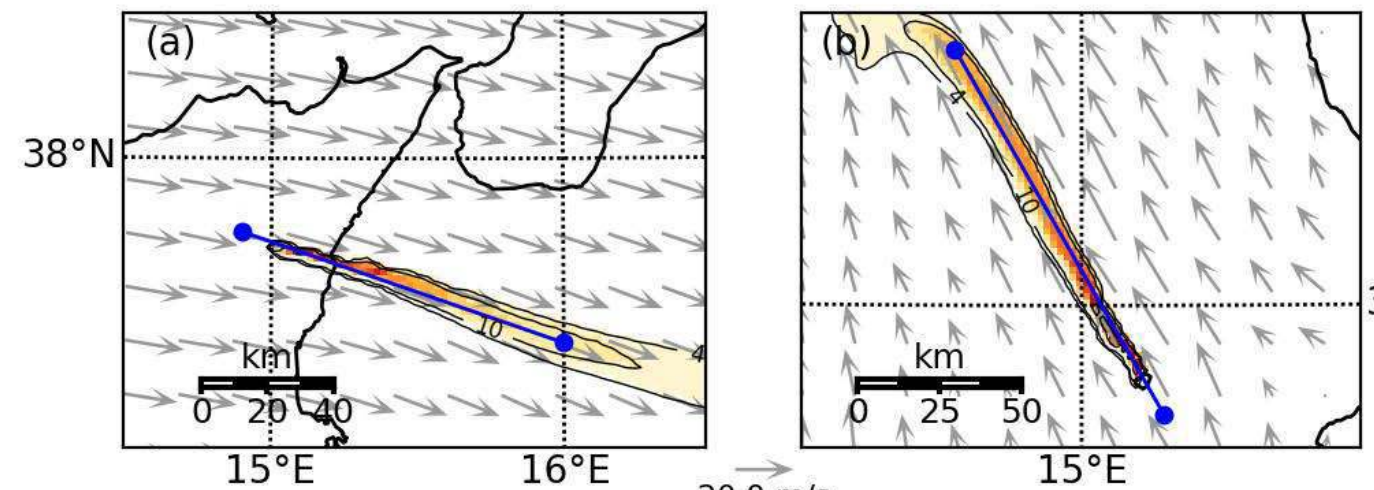

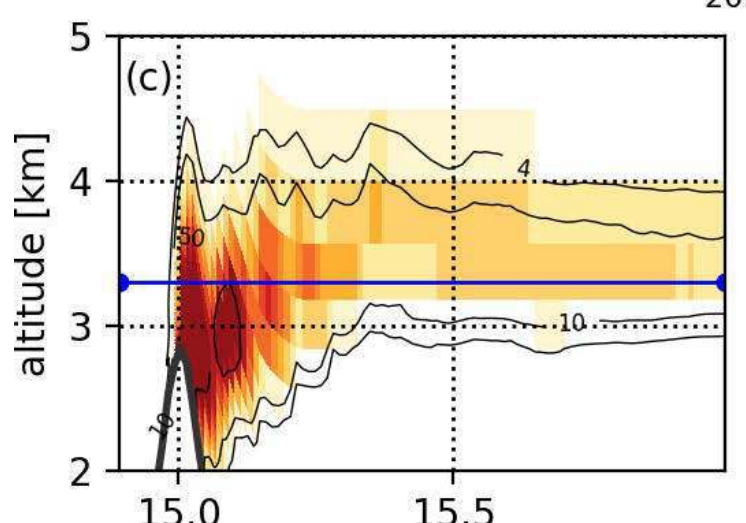

15.0

15.5

$20.0 \mathrm{~m} / \mathrm{s}$
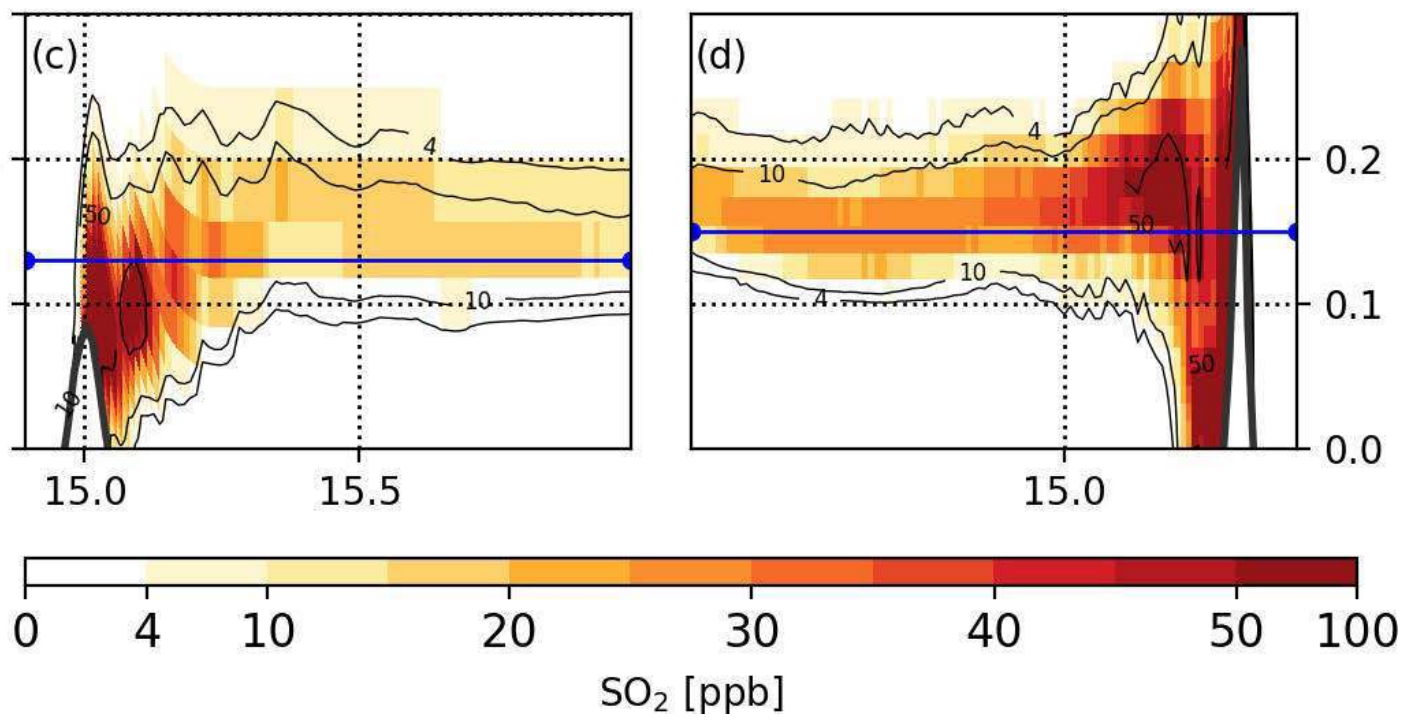

Figure 3. Simulated $\mathrm{SO}_{2}$ concentration (ppb; colors) at 15 UTC on 15 June 2016 for ETNA15 flight (first column) and at 8 UTC on 16 June 2016 for STRO16 flight (second column) on horizontal (a,b) and vertical (c,d) cross sections (domain at $2 \mathrm{~km}$ resolution). Blue lines correspond to cross-sections locations. Grey arrows in (a) and (b) correspond to horizontal wind speed at the altitude of the cross sections.

The observed $\mathrm{SO}_{2}$ (Fig.4a,b ; red line) fall within the bounds of the simulated values (Fig.4a,b ; grey lines) except at some points for ETNA15 flight where observed the SO concentration have wider spreadhigher values than the simulated one. It can also be noticed that The temporal evolution of the observed $\mathrm{SO}_{2}$ presents a smoother gradientvariability than the simulated ones (for example, at 15 UTC on 15 June). This is due to the sensor temporal resolution smoothing the $\mathrm{SO}_{2}$ concentration over $60 \mathrm{~s}$. However, fFor both flights, the simulation reproduces the peak of $\mathrm{SO}_{2}$ concentration measured by the aircraft, indicating the correct position of the simulated plumes. For ETNA15 (Fig. 4a), the three main $\mathrm{SO}_{2}$ peaks are located close to the volcanos vent (Fig. 4e). The measured $\mathrm{SO}_{2}$ concentration increases as the aircraft approaches the volcanic injection height. Close to the volcano vent at $14 \mathrm{~h} 15 \mathrm{UTC}$, the observed concentration of $\mathrm{SO}_{2}$ is approximately $35 \mathrm{ppb}$ at $2800 \mathrm{~m}$ a.s.l. and increased to 80 $\mathrm{ppb}$ at $15 \mathrm{UTC}$ when the aircraft reaches more than $3000 \mathrm{~m}$ a.s.l. These peaks are well reproduced by the simulation with concentrations ranging from $40 \mathrm{ppb}$ at $14 \mathrm{~h} 15$ 
UTC to $90 \mathrm{ppb}$ at 15 UTC (close towithin $10 \%$ of difference withthe observations). For STRO16 flight (Fig. 4b), two $\mathrm{SO}_{2}$ peaks are simulated close to the volcanoes vent. First SO peak, at $7 \mathrm{~h} 30 \mathrm{UTC}$, is reproduced within $10 \%$ of the observed values $(80 \mathrm{ppb})$. However, when the aircraft approaches the volcano vent for the second time, at 9 UTC, simulated $\mathrm{SO}_{2}$ concentrations show a peak which is not measured by the aircraft: either the volcano's $\mathrm{SO}_{2}$ emissions are lower at this time (difficult to verify this without high temporal resolutionfrequency observations of the volcanic emissions) or the aircraft is measuring outside the plume or the mixing of the two plumes above Stromboli volcano (Fig. 2b) is not well positioned at the right place in the simulation. It was shown that the Stromboli volcano hasexperiences a lowexplosive event approximately every ten minutes (Blackburn et al., 1976), and the SO flux can vary by a factor of four between two explosions (Burton et al., 2009). Simulated SO emissions don't vary a lot during these 2-day of simulations (2 to $4 \mathrm{~kg}$ s ) and can also be the origin of this difference.
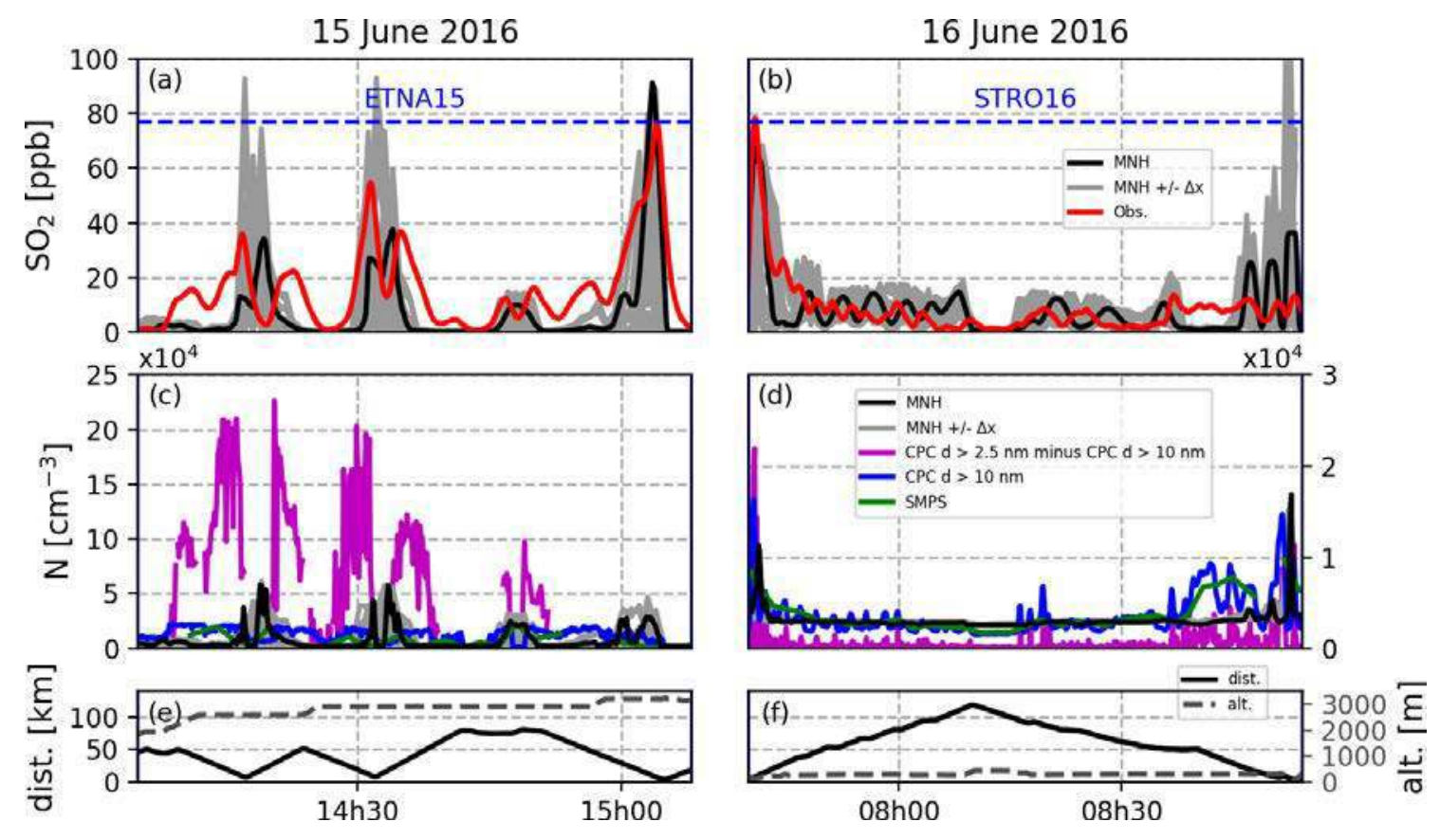

Figure 4. Observed and simulated temporal evolution of $\mathrm{SO}_{2}(\mathrm{a}, \mathrm{b})$ and aerosol concentration (c,d) for the 15 June 2016 ETNA15 flight (left panels) and for the 16 June 2016 STRO16 flight (right panels). In grey lines inGrey lines (a,b,c,d) isshowing the temporal evolution $\mathrm{SO}_{2}$ and aerosol concentration extracted from grid points around aircraft trajectories. Lowest panels $(\mathrm{e}, \mathrm{f})$ show the temporal evolution of the distance of the aircraft from the vent (black line) and the altitude of the flights (grey dashed line).

\subsection{Total aerosol number}

For ETNA15 flight (Fig. 4c), the observed number of aerosols is mainly composed of aerosols with a sizediameters between $2.5 \mathrm{~nm}$ and $10 \mathrm{~nm}$ (in diameter), as described in Sahyoun et al. (2019). The simulation does not represent this particle size because, as explained in the Section 3, the simulated aerosol distribution is defined by only 2 modes: Aitken and accumulation and the median diameter of these modes is too coarse to represent particle sizes with diameters lower than $20 \mathrm{~nm}$. Another mode, the nucleation mode, would be needed to be able to properly represent these particles. 


\section{Accepted Article}

Despite this numerical limitation, the number of simulated aerosols is comparable to that observed by the CPC (>10 nm) (blue line in Fig. 4c) and the SMPS (green line in Fig. 4c) which are well represented by the two simulated modes. The number of simulated (black line in Fig.4c) and observed (green and blue lines ; Fig.4c) aerosols with diameter higher than $10 \mathrm{~nm}$ are in confidence withpresent less than $8 \%$ of differences. The maximum simulated and observed aerosol concentrations of aerosol with diameter higher than $10 \mathrm{~nm}$ is around $50000 \mathrm{~cm}^{-3}$. With the exception of a short period at 15 UTC wherewhen no observations data are available, that peakthe peaks ofin number aerosols concentration (Fig.4c) are well correlated with peaks ofin $\mathrm{SO}_{2}$ concentrations (Fig.4a) for both observations and simulation.

Unlike ETNA15, the number of aerosols observed in STRO16 is mainly composed of aerosols with diameters greater than $10 \mathrm{~nm}$, which is therefore comparable with the number of simulated aerosols. This can beis explained by the higher condensation sink in the MABL than in the FT (Fig. S1), which tends to inhibit nucleation and confirms by thethrough simulations the hypothesis proposed by Sahyoun et al. (2019). The maximum aerosol concentration are localised close to the vent (Fig. 4d), where SO concentrations are maximumhighest (Fig. 4b) : whether at 7 UTC or 8 h50 UTC, aerosol concentrations exceed $20000 \mathrm{~cm}^{-3}$. Many vVariations in the number of observed aerosols are related to the aircraft's sinuous trajectory, which had the objective of This trajectory was aiming at detecting the plume's boundaries. This variabiliy makes it difficult for the model to accurately simulate aerosol number concentration which is not well reproduced by simulated aerosol concentrations. At about $8 \mathrm{~h} 40$ UTC, an increase in the number of aerosols is observed but not simulated: this is explained by the fact that in the simulation, the aircraft is outside the plume $\left(\mathrm{SO}_{2}\right.$ concentration $<4 \mathrm{ppb}$ (Fig. 4a)). Near the volcano's vent at $8 \mathrm{~h} 50$ UTC, the CPCs show a high concentration of particles while littledespite low concentrations $\mathrm{SO}_{2}$ concentration isbeing observed. As mentioned aboveearlier, it can comes from a change in the volcano regime or from a smoothing of the $\mathrm{SO}_{2}$ data by the instrumental time averageaveraging.

Note that total simulated aerosol number is very sensitive to new particle formation from nucleation processes that can vary by a few orders of magnitude with respect to the nucleation parameterization (Maattanen et al., 2018). This can also explained discrepancies between simulation and observation.

\subsection{Aerosol size distribution}

Fig. 5a and 5b show the observed and simulated distributions at all aicraft positions, the cut-off diameters of the observations is equal to $18 \mathrm{~nm}$. Two modes are clearly visible in the observations (black line) and are well reproduced by the simulation (green line) with mean diameters around $25 \mathrm{~nm}$ for mode iait and $80 \mathrm{~nm}$ for mode jacc for ETNA15 flight. Due to condensation in the MABL, the aerosols on STRO16 flight are larger with median diameters equal to $30 \mathrm{~nm}$ and $90 \mathrm{~nm}$, for mode iait and jacc, respectively.

The evolution of these size distributions is illustrated as a function of time for observations (Fig. 5c and 5d) and differences between observation and simulation (Fig. 5e and 5f). It should be noted that the time resolution of the SMPS is $84 \mathrm{~s}$ and that of the simulation is $8 \mathrm{~s} 4 \mathrm{~s}$ for the hosted domain and $2 \mathrm{~s}$ for the nested domains. Time interpolation of simulated distributions is therefore necessary to compute differences between observations and simulations, this interpolation smoothes high simulated aerosol concentrations of mode iait (red lines in Fig. 5a and 5b).

For ETNA15 and STRO16 flights, the observed distributions show high aerosol number concentration of mode ait near the vent (black curve; Fig. 5c and 5d). Values exceed $10^{4} \mathrm{~cm}^{-3}$. Around these points, the differences between observed and simulated aerosol number concentration is important, more than $150 \%$. This is mainly due to the temporal interpolation of the simulated distribution smoothing high concentrations. 

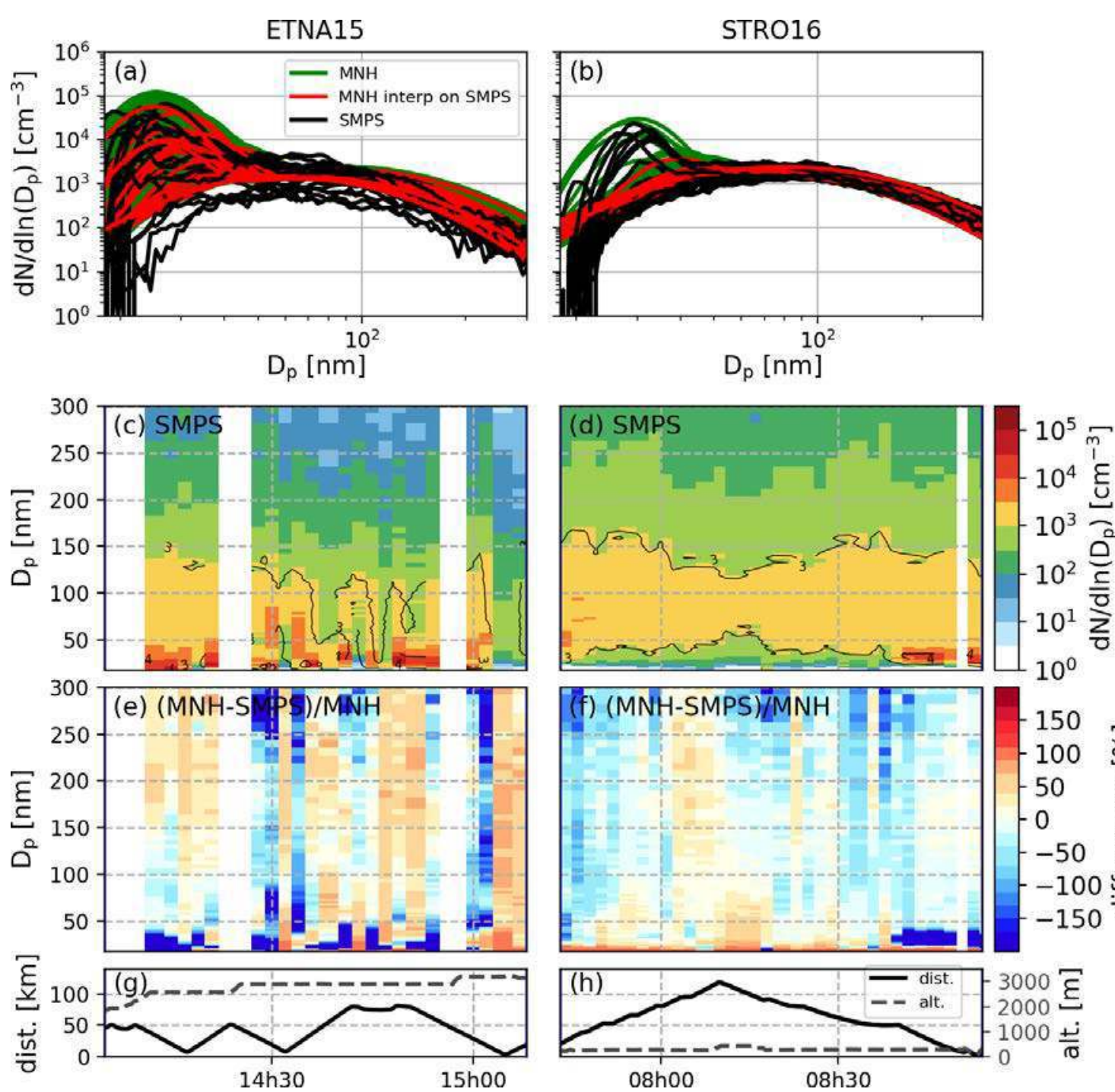

Figure 5. In (a) and (b) the aerosol number size distribution $\left(\mathrm{dN} / \mathrm{d} \ln \left(\mathrm{D}_{p}\right)\left[\mathrm{cm}^{-3}\right]\right)$ observed by the SMPS onboard the aircraft and simulated for the ETNA15 and STRO16 flights, respectively. Temporal evolution of the aerosol number size distribution $\left(\mathrm{dN} / \mathrm{d} \ln \left(\mathrm{D}_{p}\right)\left[\mathrm{cm}^{-3}\right]\right)$ observed by the SMPS for both the (c) ETNA15 and (d) STRO16 flights and the difference between observations and simulations for (e) ETNA15 and (f) STRO16 flights in \%. Thick black lines in (c) and (d) represent the isovalue $10^{3}$ and $10^{4}\left[\mathrm{~cm}^{-3}\right]$. Lowest panels show the temporal evolution of the distance of the aircraft from the vent (black line) and the altitude of the flights (grey dashed line) for both (g) ETNA15 and (h) STRO16 flights.

For ETNA15, there is a high concentration of aerosol far from the vent at about $14 \mathrm{~h} 45$ UTC, which is present in both the observations and simulations. At that moment the aircraft turns around the volcanic plume (Fig.1) and most certainly passes inside the plume. Close to the vent of Stromboli, observation show also higher concentration of aerosols than simulation. This overestimation can be due to the volcanic emissions evolution, which is not taken into account in the simulation. With regard to STRO16 flight, there is an area with high aerosol number concentrations of mode iait (also visible in Fig. 4d), at about $8 \mathrm{~h} 40$ UTC and $40 \mathrm{~km}$ from the vent, which is not 
reproduced by the simulation and which is most certainly due to the fact that the simulated aircraft is not exactly in the plume at this time. Between $50 \mathrm{~nm}$ and $300 \mathrm{~nm}$, observed aerosol number concentration overestimatethe simulated aersosol number concentration underestimates by 6 and $16 \%$ the simulated aerosol number concentrationthe observed aerosol number concentration for ETNA15 (Fig. 5e) and STRO16 (Fig. 5f) flights, respectively.

Despite differences in the number of aerosols observed and simulated, the simulation reproduces the temporal variability of $\mathrm{SO}_{2}$ and aerosol size distributions, making the study on the aging of these two plumes valuable.

\section{Volcanic plumes aging}

The following section is interested in characterizing the differences in aging between a volcanic plume located in the FT (Etna volcano ; ETNA15 flight) and one located in the MABL (Stromboli volcano ; STRO16 flight).

\subsection{Free troposphere : Etna}

The impact of the volcanic plume on the spatial distribution of the simulated median diameter for mode iait and jacc is clearly noticeable (Fig. 6a,b). For mode iait, the median diameter is the smallest around $25 \mathrm{~nm}$ near the vent (Fig. 6a,c), where the maximum nucleation rate is presentdetected (black curve on Fig. 6a). Along the volcanic plume the aerosols of mode iait grow by coagulation and condensation until they reach a distribution with a median diameter around $35 \mathrm{~nm}$ (Fig. 6a,c ; S2). The maximum number of aerosols is located observed within the plume with concentrations above $20000 \mathrm{~cm}^{-3}$. Due to nucleation, the median diameter of mode iait is two times smaller in the plume than outside. However, for mode jacc, it is the opposite, the aerosols are larger in the plume than outside. Close to the volcano vent (approximately $70 \mathrm{~km}$ ), coagulation processes preremain dominate as long as the nucleation is significant. Then it is the condensation process that mainly increases the median diameter of the mode jacc (Fig. S1 ; S2) from $60 \mathrm{~nm}$ to more than $90 \mathrm{~nm}$ away from the vent. Unlike mode iait, the number of aerosols in mode jacc doesn't change along the track, mainly because condensation process, which is the dominant process implicated in the variation of the distribution of mode jacc, have no impact on aerosol number.

\subsection{Marine atmospheric boundary layer : Stromboli}

As in Figure 6, Figure 7 shows evolution of the aerosol parameters and size distributions in the Sromboli volcanic plume localized in the MABL (STRO16 flight).

Condensation process which is effective up to $100 \mathrm{~km}$ from the vent causes the rapid growth of the median diameter of modes iait and jacc (Fig. S4). For mode iait, the median diameter has doubled indoubles over $100 \mathrm{~km}$, from $30 \mathrm{~nm}$ near the vent to more than $60 \mathrm{~nm}$ at $100 \mathrm{~km}$ from it (Fig. 7a). For mode jacc, the median diameter passingincreases from $60 \mathrm{~nm}$ close to the vent to more than $90 \mathrm{~nm}$ at 100 $\mathrm{km}$ from it. For both iait and jacc modes, the aerosols generated by the plume are larger than those present in the surrounding environment. In this volcanic plume, nucleation process ises are only present in the vicinity of the vent creating high aerosol number concentration of mode iait $\left(25000 \mathrm{~cm}^{-3}\right)$ in the first $20 \mathrm{~km}$ from the vent (Fig. 7c ; S3). Aerosol number concentration decreases along the volcanic plume due to intramodal coagulation passing from $25000 \mathrm{~cm}^{-3}$ and $3500 \mathrm{~cm}^{-3}$ close to the vent to less than $5000 \mathrm{~cm}^{-3}$ and $2900 \mathrm{~cm}^{-3}$ at more than $50 \mathrm{~km}$ from it, for mode iait and jacc respectively (Fig. S3). 
(a) mode ait

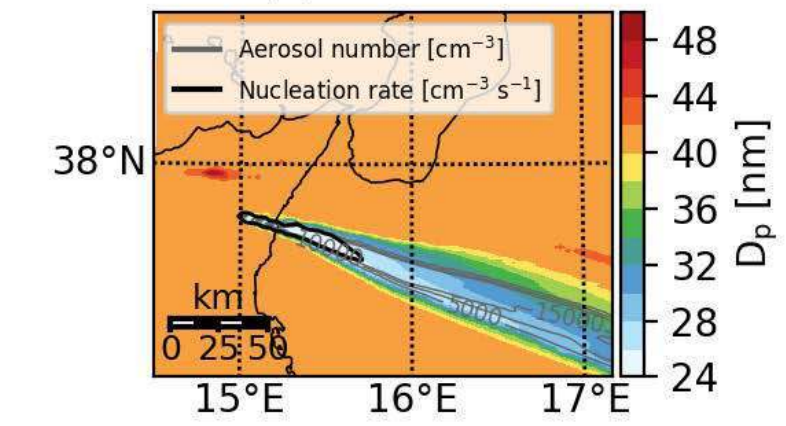

(b) mode acc

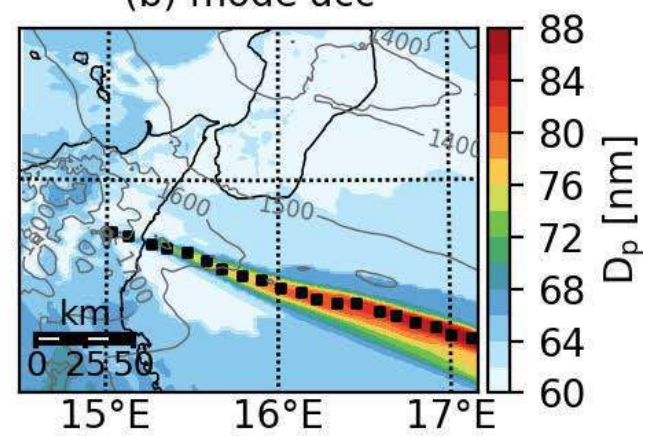

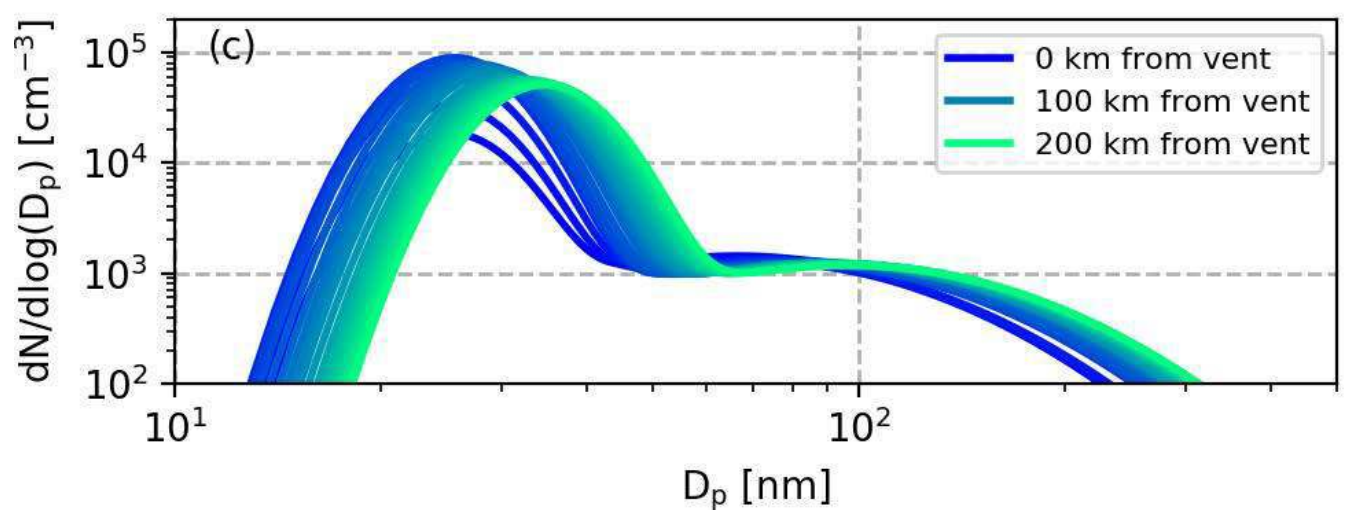

Figure 6. Spatial distribution of the simulated median diameter (nm; colors) at 15 UTC on 15 June 2016 at $3.3 \mathrm{~km}$ above sea level for mode iait (a) and mode jacc (b). Black contours in (a) correspond to isoline $5 \times 10^{5} \mathrm{~cm}^{-3} \mathrm{~s}^{-1}$ for the nucleation rate and grey contours in (a) and (b) to aerosols number in $\mathrm{cm}^{-3}$. In (c), the evolution of the aerosol size distribution extracted along the volcanic plume (black squares on (b)), colors correspond to the distance from the vent in $\mathrm{km}$.

\subsection{Impact on cloud condensation nuclei}

The impact of these two volcanic plumes on cloud microphysics is estimated through a calculation on condensation nuclei based on the work of Abdul-Razzak et al. (1998) and Abdul-Razzak and Ghan (2000). From the particle size distributions extracted along the two plumes (black squares in Fig. 6c and 7c) and the chemicalgasphase composition of the volcanic plumes (Fig. S5 and S6), it is possible to calculate a number of aerosols acting as condensation nuclei for a given supersaturation, corresponding to $S{ }_{x}$ in Abdul-Razzak and Ghan (2000). Three supersaturations (0.1\%, $0.3 \%$ and $0.5 \%$ ) are chosen because they represent meteorological conditions present in fog and maritime cumulus that can be encountered in the Mediterranean sea, close to Etna and Stromboli volcanoes (Seinfeld, 2006). The evolution of cloud condensation nuclei in both plumes (ETNA15 and STRO16) at these three supersaturations are shown in Fig. 8.

Fig. 8 shows that the aerosols present in the Etna and Stromboli plumes will act differently on the formation of CCN. As expected, the aerosols acting as CCN are always higher in the case of a volcanic plume (plain versus dots lines in Fig 8a,b). The volcanic plumes lead to an increase in the number of potentially activable aerosols as CCN as it is mentioned in literature (Mather et al., 2003).

For the Etna volcanic plume (ETNA15 ; Fig. 8a), a supersaturation of $0.5 \%$ must be achieved to see an effect on CCN formation. For this supersaturation, the number of activated aerosols increases with distance, with numbers going from $2000 \mathrm{~cm}^{-3}$ near 


\section{(a) mode ait}

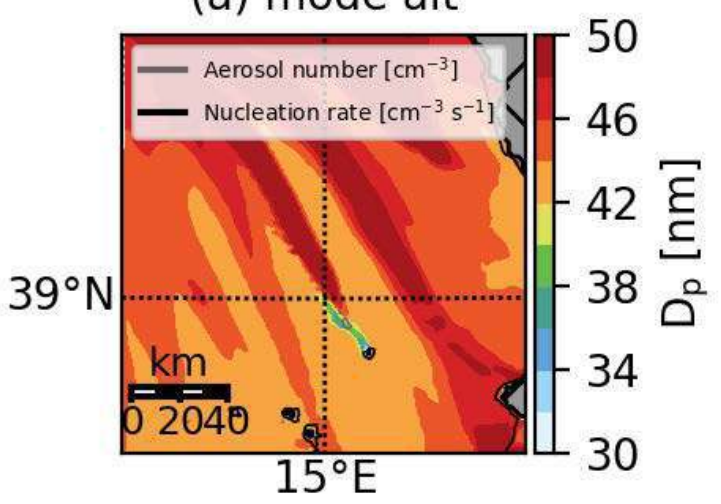

(b) mode acc

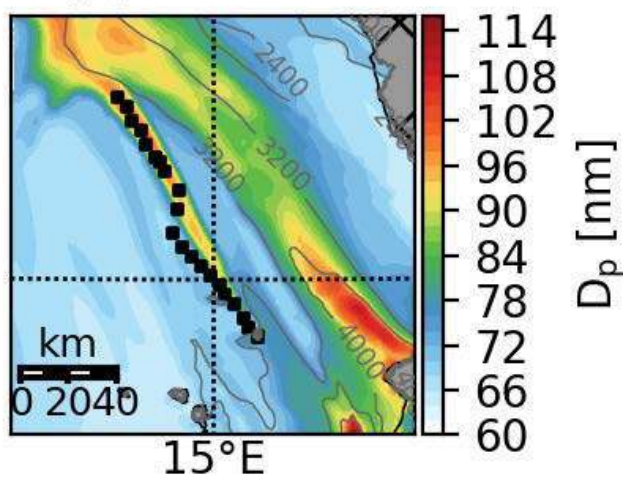

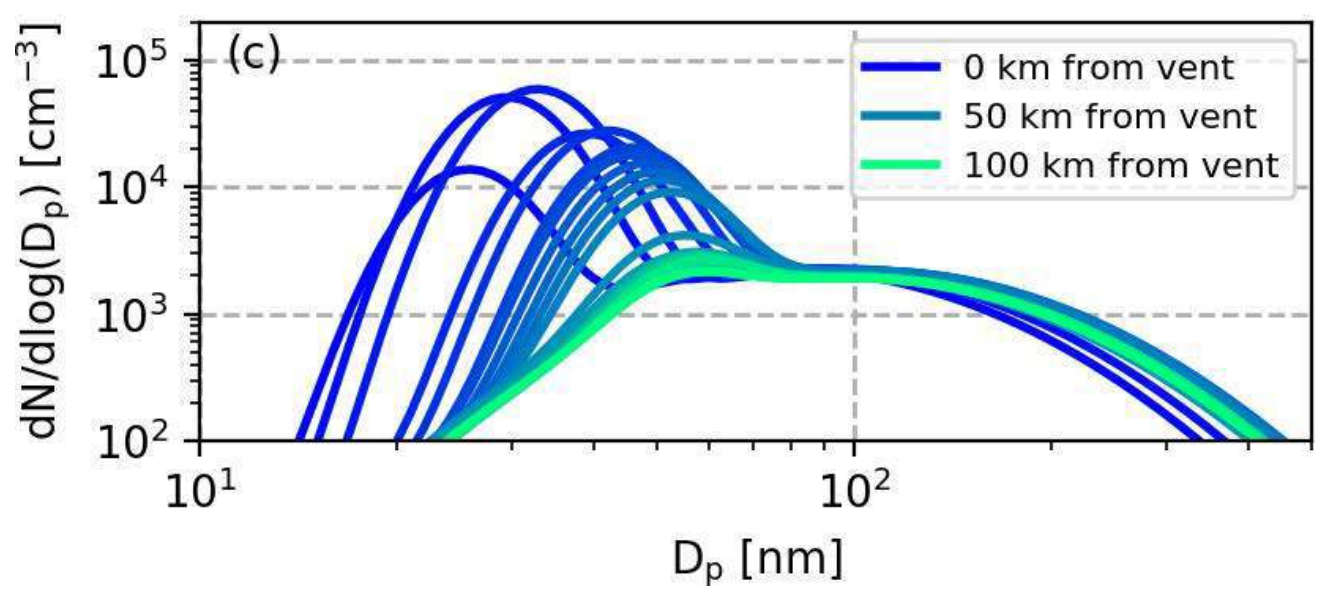

Figure 7. Spatial distribution of the simulated median diameter (nm; colors) at 8 UTC on 16 June 2016 at $150 \mathrm{~m}$ above sea level for mode iait (a) and mode jacc (b). Black squares correspond to points extracted to look at aerosol size distribution evolution (c). Evolution of the aerosol size distribution extracted along the volcanic plume (black squares on (b)).

Table 2. Critical diameter $[\mathrm{nm}]$ for the three supersaturation considered $(0.1,0.3$ and $0.5 \%)$ for mode iait and jacc.

\begin{tabular}{ccccc}
\hline & \multicolumn{2}{c}{ ETNA15 } & \multicolumn{2}{c}{ STRO16 } \\
\hline mode & ait & acc & ait & acc \\
\hline critical diameter $(0.1 \%)[\mathrm{nm}]$ & 110.6 & 119.4 & 100.4 & 104.2 \\
critical diameter $(0.3 \%)[\mathrm{nm}]$ & 53.2 & 57.4 & 48.4 & 49.8 \\
critical diameter $(0.5 \%)[\mathrm{nm}]$ & 38.4 & 40.6 & 34.8 & 35.6 \\
\hline
\end{tabular}

the vent to $8000 \mathrm{~cm}^{-3}$ at approximately $200 \mathrm{~km}$. This increase in the number of CCNs is mainly due to the growth of mode iait (Fig. 6c and Fig. 8c). At more than 100 $\mathrm{km}$ from the vent the aerosols have reached a diameter large enough to approach the critical radius (Table 2) and can thus be activated (Fig. 8c). Near emission, less than $5 \%$ of the aerosols of mode iait are activated while in the distance, more than $30 \%$ are activated. The number of aerosols activated for mode jacc doesn't vary a lot along the volcanic plumes and remains around the value near the vent corresonping to the background value. The further away from the plume, the larger the aerosols in mode jacc have grown and the more they become but their number decreases, so that the 


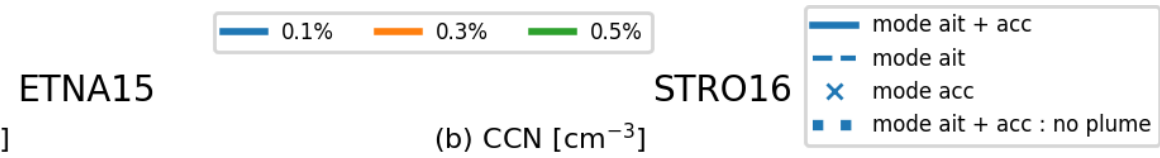

\section{(a) $\mathrm{CCN}\left[\mathrm{cm}^{-3}\right]$}
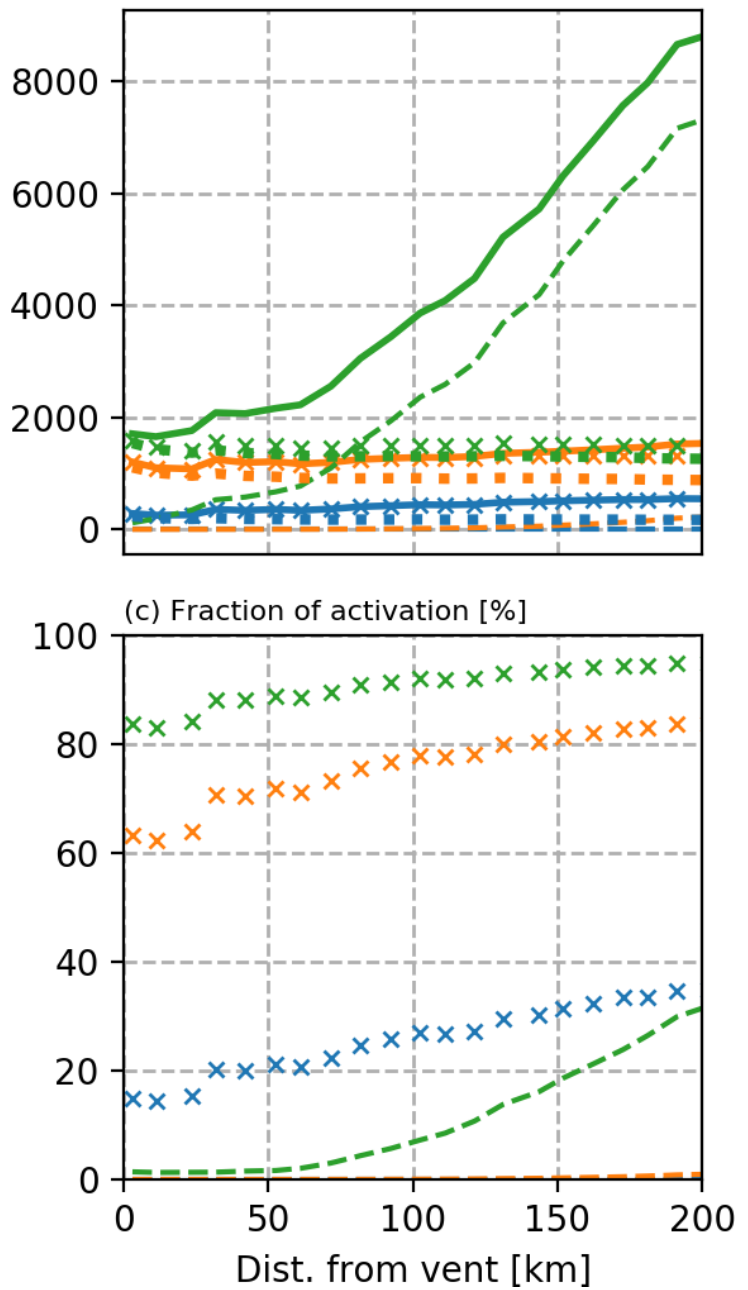

(b) $\mathrm{CCN}\left[\mathrm{cm}^{-3}\right]$

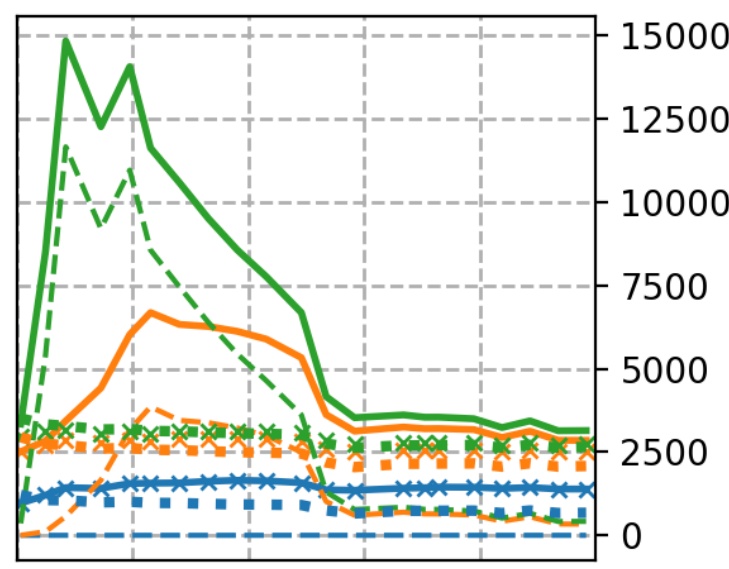

(d) Fraction of activation [\%]

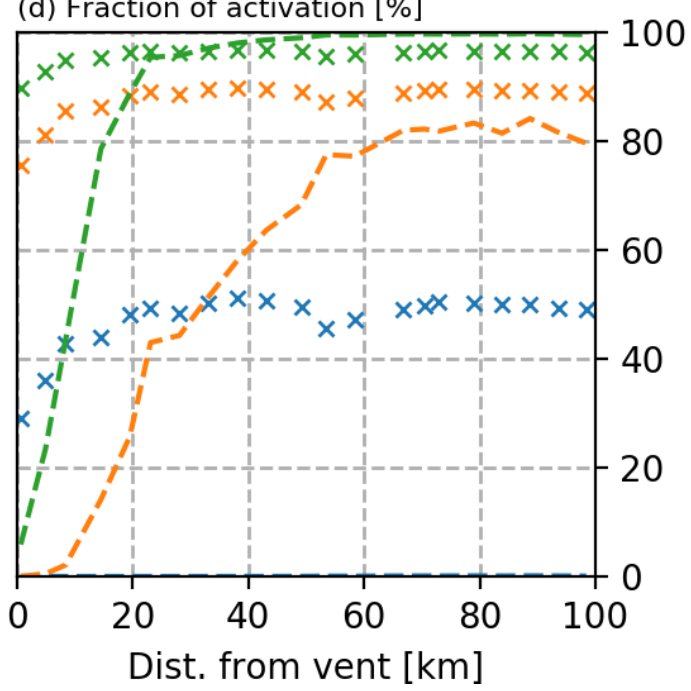

Figure 8. Evolution of the number of aerosols that can be act as cloud condensation nuclei $(\mathrm{a}, \mathrm{b})$ and fraction of aerosol activated $(\mathrm{c}, \mathrm{d})$ in function of the distance from the vent for Etna (ETNA15 ; left panels) and Stromboli (STRO16 ; right panels) volcanic plumes. In (a) and (b), mode jacc contribution is given by differences between total and mode iait contributions and is not plot in the figure for more clarity.

number of activable aerosols in mode jacc is relatively constant when moving away from the vent.The further away from the plume, the larger the aerosols in mode acc have grown and the more they become but their number decreases (Fig. 6c). The number of activable aerosols in mode acc is therefore relatively constant when moving away from the vent and correspond approximately to the absolute background activable aerosol concentration $\left(\approx 1500 \mathrm{~cm}^{-3}\right.$; Fig. 8a). For the supersaturations $0.1 \%$ and $0.3 \%$, the critical activation diameters are too large $(110.6 \mathrm{~nm}$ and $53.2 \mathrm{~nm}$, respectively ; Tab. 2) compared to the maximum median diameter of mode iait $(35 \mathrm{~nm})$ making the effect of these volcanic plumes on CCN formation negligible at thatthese supersaturations.

For Stromboli (STRO16) volcanic plume, the number of aerosols close to the vent that can act as CCN is greater than far from it. As said before,This is a result 


\section{Accepted Article}

of the high condensation sink, where the aerosols of the mode iait grow very quickly in the MABL (Fig. 7c), which make them activable as CCN close to the vent, at less than $20 \mathrm{~km}$ from it(lower than $20 \mathrm{~km}$ ). Effect of aerosols on CCN formation is visible for supersaturation of 0.3 and $0.5 \%$ with the number of CCN exceeding 12000 and 6 $000 \mathrm{~cm}$, respectively. The number of activated aerosols for mode jacc doesn't vary a lot along the volcanic plume and is equal to $1000 \mathrm{~cm}^{-3}$ which make their impact on CCN formation insignificant in comparison to aerosols in mode iait.

\section{Discussion and conclusion}

This work provides a detailed analysis of theThe formation and aging of Etna and Stromboli volcanic plumes is studied in this articleusing a combination of numerical simulations and in-situ observations. To the best of our knowledge, the observations available from the STRAP campaign as well as the simulations carried out using a 3D atmospheric model with online chemistry and aerosol at hectometricsub-kilometric resolution for studying volcanic plumes are unique. The evaluation of the simulation with available observations showed that the numerical simulation sucessfully reproduceds the position and structure of the volcanic plumes in terms ofwith respect to SO concentration. With regard to the distribution of aerosolsHowever, for aerosol particles (median diameter and number concentration), it was shown that it was difficult to compare the data with the model. This was mainly a result of high because a large numbers of aerosols present with diameters smaller than what is used in the model $(10 \mathrm{~nm})$. For aerosols larger than $10 \mathrm{~nm}$, the simulation reproduces wellthe number and size of particles in the Aitken and accumulation modes, with differences lower than $10 \%$ and $5 \%$ on the aerosol number and median diameter, respectively.

The size distribution of aerosols between volcanic plumes located in the FT for Etna (ETNA15) and in the MABL for Stromboli (STRO16) doesn't evolve in the same way making their potential effect on climate and environnement different. The median diameter of mode iait increases more than 5 times faster in the MABL $(\approx$ $0.3 \mathrm{~nm} \mathrm{~km})$ than in the FT $\left(\approx 0.05 \mathrm{~nm} \mathrm{~km}^{-1}\right)$. The subtle balance between condensation and nucleation processes is responsible of this difference. Once formed by the oxidation of sulfur dioxide, sulfuric acid which has a very low vapor pressure will condense onto preexisting particles or participate in nucleating new particles. These competitive processes between condensation on preexisting aerosols and nucleation are known (Middleton \& Kiang, 1978; Binkowski \& Shankar, 1995; Campbell et al., 2014) but rarely well represented in chemical transport models and to our knowledge never for volcanic plumes studies. It is complicated to represent it numerically because it is extremely sensitive to the chemical species concentration involved in the production of sulfuric acid $\left(\mathrm{SO}_{2}, \mathrm{O}_{3}, \mathrm{OH}, \ldots\right)$, the aerosol size distribution and the properties of the air mass. Based on sensitivity experiments with 0D simulations using the same routines as the 3D simulations (Text S1 in the Supporting Information), the impact of the air masses characteristics and injection height on the evolution of the aerosol size distribution is assessed. The air temperature, the air density, the water vapor content and the background aerosol concentration significantly affect the competition between condensation and nucleation and therefore the production of new aerosols : (i) the higher the temperature or the higher the background aerosol concentration, the higher the condensation sink, (ii) the higher the density or the higher the water vapor content, the higher the production of sulfuric acid. If the condensation sink is large enough, nucleation will be inhibited even if large quantities of sulfuric acid are present. In the present study, due to higher temperature (Fig. S7) and aerosol numbers and diameters for the mode jacc, the condensation sink (Fig. S8) is higher in the MABL than in the FT which tends to inhibit nucleation and causes aerosols to grow more rapidly in the MABL than in the FT. In addition, unlike the FT, the median diameter of the mode iait in the MABL approaches or even exceeds the median diameter of the surrounding aerosols. For future global or regional scales simulations of volcanic 


\section{Accepted Article}

plumes, the injection height of volcanic plumes has to be considered with attention. Errors on the position of volcanic plumes will influence a lot the evolution of aerosol distribution, in particularly their size and number that can have an impact on cloud microphysics, local meteorology and climate.

Independent of the location of the plume median diameter of mode jacc doesn't evolve enough to act significantly as CCN compared to a case where no plume is present. Strong differences on potentially activable CCN formation for both volcanic plumes are due to differences in the growth of mode iait between FT and MABL. In the FT, supersaturation of $0.5 \%$ has to be reached to activate aerosols as CCN. In that case, aerosols are mainly activated far from the vent, at more than $200 \mathrm{~km}$ from it : the median diameter of the mode iait grow sufficiently to reach critical diameter. In comparison, in the MABL close to the vent, at less than $20 \mathrm{~km}$ from it, median diameter of mode iait reaches critical diameter with supersaturation lower than in FT $(0.3 \%)$. Our simuations illustrate that aerosols formed from volcanic plumes contribute to a 5 fold increase in potential CCN number.

This result confirms that for both passive degassing or low-eruptive events in the FT, volcanic gases and aerosols have strong impacts on CCN concentration up to at least $200 \mathrm{~km}$. Furthermore, aerosols created by nucleation are close to nanometric sizes and can causes environmental ans human and transport perturbations.

Potential impact of these kind of emissions on current climate models can be strongimportant as they are imply in radativeaffect the radiative budget via direct , semi-direct and/or indirect aerosols effect. Increases in this number of CCN will result in the increase in cloud droplet number will can therefore result in a higher surface cooling. However, to provide accurate guidance to climate modellers as in Fanourgakis et al. (2019), it is necessary to generalize these results by multiplying the simulated situations according to the intensity of degassing and weather conditions to obtain a statistical representation of the CCN formation on this kind of volcanoes. Furthermore, thisthese kind of volcanic emissions are constantpresent all overthroughout the year and will have a continuous impact on the radiative budget compared to less frequent explosive eruptions. It is therefore important to study any volcanoes like Etna and Stromboli which are strong gases emitters and therefore contribute, even during passive period of activity, into producing aerosols that may impact on atmospheric climate and pollution.

\section{Acknowledgments}

This work was carried out in the framework of the STRAP project, which benefits from French government support managed by the Agence Nationale de la Recherche. ClerVolc project is also acknowledged for financing the ATR42 flights, funded by the French government "Laboratory of Excellence" initiative. The authors would also

like to extend special thanks to the pilots and flight crew from SAFIRE for all their enthusiasm and support during the measurement campaign aboard the ATR42 aircraft. The simulations were performed on the supercomputer "beaufix" of MétéoFrance in Toulouse, France. The models used in this paper are open-source and freely available at the following websites: http://mesonh.aero.obs-mip.fr. The observations data are available in University of La Réunion servers: https://osur.univreunion.fr/recherche/strap/database.

\section{References}

Abdul-Razzak, H., \& Ghan, S. J. (2000, March). A parameterization of aerosol activation: 2. Multiple aerosol types. Journal of Geophysical Research: Atmospheres, 105(D5), 6837-6844. Retrieved 2019-04-10, from http://doi.wiley .com/10.1029/1999JD901161 doi: 10.1029/1999JD901161

Abdul-Razzak, H., Ghan, S. J., \& Rivera-Carpio, C. (1998, March). A parameter- 
ization of aerosol activation: 1. Single aerosol type.

Research: Atmospheres, 103(D6), 6123-6131.

Journal of Geophysical http://doi.wiley.com/10.1029/97JD03735 doi: 10.1029/97JD03735

Allard, P., Aiuppa, A., Loyer, H., Carrot, F., Gaudry, A., Pinte, G., ... Dongarr, G. (2000, April). Acid gas and metal emission rates during long-lived basalt degassing at Stromboli Volcano. Geophysical Research Letters, 27(8), 1207-1210. Retrieved 2019-07-23, from http://doi.wiley.com/10.1029/1999GL008413 doi: $\quad$ 9/1999GL008413

Bechtold, P., Bazile, E., Guichard, F., Mascart, P., \& Richard, E. (2001, April). A mass-flux convection scheme for regional and global models. Quarterly Journal of the Royal Meteorological Society, 127(573), 869-886. Retrieved 2018-0920, from http://doi.wiley.com/10.1002/qj.49712757309 doi: 10.1002/qj .49712757309

Berthet, G., Jgou, F., Catoire, V., Krysztofiak, G., Renard, J.-B., Bourassa, A. E., ... Guimbaud, C. (2017, February). Impact of a moderate volcanic eruption on chemistry in the lower stratosphere: balloon-borne observations and model calculations. Atmospheric Chemistry and Physics, 17(3), 2229-2253. Retrieved 2018-09-27, from https://www . atmos-chem-phys.net/17/2229/2017/ doi: p-17-2229-2017

Binkowski, F. S. (2003). Models-3 Community Multiscale Air Quality (CMAQ) model aerosol component 1. Model description. Journal of Geophysical Research, 108(D6). Retrieved 2018-09-20, from http://doi.wiley.com/ 001JD001409 doi: 10.1029/2001JD001409

Binkowski, F. S., \& Shankar, U. (1995). The Regional Particulate Matter Model: 1. Model description and preliminary results. Journal of Geophysical Research, 100 (D12), 26191. Retrieved 2019-08-04, from http://doi.wiley.com/ 10.1029/95JD02093 doi: 10.1029/95JD02093

Blackburn, E. A., Wilson, L., \& Sparks, R. S. J. (1976, August). Mechanisms and dynamics of strombolian activity. Journal of the Geological Society, 132(4), 429-440. Retrieved 2019-05-03, from http://jgs.lyellcollection.org/ lookup/doi/10.1144/gsjgs.132.4.0429 doi: 10.1144/gsjgs.132.4.0429

Boulon, J., Sellegri, K., Hervo, M., \& Laj, P. (2011, July). Observations of nucleation of new particles in a volcanic plume. Proceedings of the $\mathrm{Na}$ tional Academy of Sciences, 108(30), 12223-12226. Retrieved 2019-04-08, from http://www.pnas.org/cgi/doi/10.1073/pnas.1104923108 doi: as. 1104923108

Burton, M., Caltabiano, T., Mur, F., Salerno, G., \& Randazzo, D. $(2009$, May). $\quad$ SO2 flux from Stromboli during the 2007 eruption: Results from the FLAME network and traverse measurements. Journal of Volcanology and Geothermal Research, 182(3-4), 214-220. Retrieved 2019-05-03, from https://linkinghub.elsevier.com/retrieve/pii/S0377027308006240 doi: $10.1016 /$ j.jvolgeores.2008.11.025

Campbell, P., Mills, M., \& Deshler, T. (2014, January). The global extent of the mid stratospheric CN layer: A three-dimensional modeling study: The Global Stratospheric CN Layer. Journal of Geophysical Research: Atmospheres, 119(2), 1015-1030. Retrieved 2019-08-22, from http://doi.wiley.com/ 013JD020503 doi: 10.1002/2013JD020503

Carn, S., Clarisse, L., \& Prata, A. (2016, February). Multi-decadal satellite measurements of global volcanic degassing. Journal of Volcanology and Geothermal Research, 311, 99-134. Retrieved 2018-10-31, from https://linkinghub .elsevier.com/retrieve/pii/S0377027316000032 doi: 10.1016/j.jvolgeores .2016 .01 .002

Colella, P., \& Woodward, P. R. (1984, April). The Piecewise Parabolic Method (PPM) for gas-dynamical simulations. Journal of Computational Physics, 54(1), 174-201. Retrieved 2018-09-18, from http://linkinghub.elsevier 


\section{Accepted Article}

.com/retrieve/pii/0021999184901438 doi: 10.1016/0021-9991(84)90143-8

Crassier, V., Suhre, K., Tulet, P., \& Rosset, R. ～(2000, January). Development of a reduced chemical scheme for use in mesoscale meteorological models. Atmospheric Environment, 34(16), 2633-2644. Retrieved 2018-09-18, from http://linkinghub.elsevier.com/retrieve/pii/S135223109900480X doi: 352-2310(99)00480-X

Cuxart, J., Bougeault, P., \& Redelsperger, J.-L. ～(2000, January). ～A turbulence scheme allowing for mesoscale and large-eddy simulations. Quarterly Journal of the Royal Meteorological Society, 126(562), 1-30. Retrieved 2018-09-18, from http://doi.wiley.com/10.1002/qj.49712656202 doi: 49712656202

Deardorff, J. W. (1980, June). Stratocumulus-capped mixed layers derived from a three-dimensional model. Boundary-Layer Meteorology, 18(4), 495-527. Retrieved 2018-09-18, from http://link.springer.com/10.1007/BF00119502 doi: $10.1007 / \mathrm{BF} 00119502$

Delmelle, P. (2003). Environmental impacts of tropospheric volcanic gas plumes. Geological Society, London, Special Publications, 213(1), 381-399. Retrieved 2018-09-27, from http://sp.lyellcollection.org/lookup/doi/10.1144/ 03.213.01.23 doi: 10.1144/GSL.SP.2003.213.01.23

Durand, J., Tulet, P., Leriche, M., Bielli, S., Villeneuve, N., Muro, A. D., \& Fillipi, J.-B. (2014, October). Modeling the lava heat flux during severe effusive volcanic eruption: An important impact on surface air quality: DURAND ET

AL. Journal of Geophysical Research: Atmospheres, $119(20), 11,729-11,742$. Retrieved 2019-01-29, from http://doi.wiley.com/10.1002/2014JD022034 doi: $\quad$ 2/2014JD022034

Emmons, L. K., Walters, S., Hess, P. G., Lamarque, J.-F., Pfister, G. G., Fillmore, D., ... Kloster, S. (2010, January). Description and evaluation of the Model for Ozone and Related chemical Tracers, version 4 (MOZART-4). Geoscientific Model Development, 3(1), 43-67. Retrieved 2018-09-18, from http:// www.geosci-model-dev.net/3/43/2010/ doi: 10.5194/gmd-3-43-2010

Fairall, C. W., Bradley, E. F., Hare, J. E., Grachev, A. A., \& Edson, J. B. $\quad$ (2003, February). Bulk Parameterization of AirSea Fluxes: Updates and Verification for the COARE Algorithm. Journal of Climate, 16(4), 571-591. Retrieved 2018-09-18, from http://journals.ametsoc.org/doi/abs/ 10.1175/1520-0442\%282003\%29016\%3C0571\%3ABPOASF $\% 3 E 2.0$. C0\%3B2 doi: 20-0442(2003)016<0571:BPOASF $\rangle$ 2.0.CO;2

Fanourgakis, G. S., Kanakidou, M., Nenes, A., Bauer, S. E., Bergman, T., Carslaw, K. S., .. Yu, F. (2019, July). Evaluation of global simulations of aerosol particle and cloud condensation nuclei number, with implications for cloud droplet formation. Atmospheric Chemistry and Physics, 19(13), 8591-8617. Retrieved 2019-07-30, from https : //www .atmos-chem-phys.net/19/8591/2019/ doi: p-19-8591-2019

Farr, T. G., Rosen, P. A., Caro, E., Crippen, R., Duren, R., Hensley, S., ... Alsdorf, D. (2007, May). The Shuttle Radar Topography Mission. Reviews of Geophysics, 45(2). Retrieved 2018-09-26, from http://doi.wiley.com/10.1029/ 2005RG000183 doi: 10.1029/2005RG000183

Freney, E. J., Sellegri, K., Canonaco, F., Colomb, A., Borbon, A., Michoud, V., ... Schwarzenbeck, A. (2014, February). Characterizing the impact of urban emissions on regional aerosol particles: airborne measurements during the MEGAPOLI experiment. Atmospheric Chemistry and Physics, 14(3), 13971412. Retrieved 2019-08-12, from https://www . atmos-chem-phys.net/14/ 1397/2014/ doi: 10.5194/acp-14-1397-2014

Gregory, D., Morcrette, J.-J., Jakob, C., Beljaars, A. C. M., \& Stockdale, T. (2010, August). Revision of convection, radiation and cloud schemes in the ECMWF integrated forecasting system. Quarterly Journal of the Royal Meteorological 
Society, 126(566), 1685-1710. Retrieved 2018-09-20, from http://doi.wiley 002/qj. 49712656607 doi: 10.1002/qj.49712656607

Guenther, A. B., Jiang, X., Heald, C. L., Sakulyanontvittaya, T., Duhl, T., Emmons, L. K., \& Wang, X. (2012, November). The Model of Emissions of Gases and Aerosols from Nature version 2.1 (MEGAN2.1): an extended and updated framework for modeling biogenic emissions. Geoscientific Model Development, 5(6), 1471-1492. Retrieved 2018-09-18, from https:// ww. geosci-model-dev.net/5/1471/2012/ doi: 10.5194/gmd-5-1471-2012

Halmer, M., Schmincke, H.-U., \& Graf, H.-F. (2002, June). The annual volcanic gas input into the atmosphere, in particular into the stratosphere:

a global data set for the past 100 years. Journal of Volcanology and Geothermal Research, 115(3-4), 511-528. Retrieved 2019-04-04, from http://linkinghub.elsevier.com/retrieve/pii/S0377027301003183 doi: $\quad$ 6/S0377-0273(01)00318-3

Haywood, J., \& Boucher, O. (2000, November). Estimates of the direct and indirect radiative forcing due to tropospheric aerosols: A review. Reviews of Geophysics, 38(4), 513-543. Retrieved 2019-01-29, from http://doi.wiley.com/ 999RG000078 doi: 10.1029/1999RG000078

Hoyle, C. R., Pinti, V., Welti, A., Zobrist, B., Marcolli, C., Luo, B., .. Peter, T.

(2011, September). Ice nucleation properties of volcanic ash from Eyjafjallajkull. Atmospheric Chemistry and Physics, 11(18), 9911-9926. Retrieved 2019-01-28, from https://www.atmos-chem-phys.net/11/9911/2011/ doi: p-11-9911-2011

Intergovernmental Panel on Climate Change (Ed.). (2014). Climate Change 2013 - The Physical Science Basis: Working Group I Contribution to the Fifth Assessment Report of the Intergovernmental Panel on Climate Change. Cambridge: Cambridge University Press. Retrieved 2018-10-30, from http://ebooks. cambridge.org/ref/id/CB09781107415324 doi: BO9781107415324

Kerminen, V.-M., Chen, X., Vakkari, V., Petj, T., Kulmala, M., \& Bianchi, F.

(2018). Atmospheric new particle formation and growth: review of field observations. Environmental Research Letters, 13(10), 103003. Retrieved from http: //stacks . iop.org/1748-9326/13/i=10/a=103003

Khodri, M., Izumo, T., Vialard, J., Janicot, S., Cassou, C., Lengaigne, M., ... McPhaden, M. J. (2017, October). Tropical explosive volcanic eruptions can trigger El Nio by cooling tropical Africa. Nature Communications, 8(1), 778. Retrieved from https://doi.org/10.1038/s41467-017-00755-6 doi: 1467-017-00755-6

Kravitz, B., Robock, A., Bourassa, A., Deshler, T., Wu, D., Mattis, I., ... Barnes, J. E. (2011, September). Simulation and observations of stratospheric aerosols from the 2009 Sarychev volcanic eruption. Journal of Geophysical Research, 116(D18). Retrieved 2018-09-27, from http://doi.wiley.com/10.1029/ 2010JD015501 doi: 10.1029/2010JD015501

Kulmala, M., Pirjola, L., \& Mkel, J. M. (2000, March). Stable sulphate clusters as a source of new atmospheric particles. Nature, 404,66. Retrieved from http:// $\mathrm{g} / 10.1038 / 35003550$

Kupc, A., Bischof, O., Tritscher, T., Beeston, M., Krinke, T., \& Wagner, P. E. (2013, February). Laboratory Characterization of a New Nano-WaterBased CPC 3788 and Performance Comparison to an Ultrafine ButanolBased CPC 3776. Aerosol Science and Technology, 47(2), 183-191. Retrieved 2019-03-19, from http://www.tandfonline.com/doi/abs/10.1080/ 02786826.2012 .738317 doi: 10.1080/02786826.2012.738317

Lac, C., Chaboureau, J.-P., Masson, V., Pinty, J.-P., Tulet, P., Escobar, J., .. . Wautelet, P. (2018, May). Overview of the Meso-NH model version 5.4 and its applications. Geoscientific Model Development, 11(5), 1929-1969. Retrieved 


\section{Accepted Article}

2018-08-06, from https://www.geosci-model-dev.net/11/1929/2018/ doi: d-11-1929-2018

Lamarque, J.-F., Bond, T. C., Eyring, V., Granier, C., Heil, A., Klimont, Z., ... van Vuuren, D. P. (2010, August). Historical (18502000) gridded anthropogenic and biomass burning emissions of reactive gases and aerosols: methodology and application. Atmospheric Chemistry and Physics, 10(15), 7017-7039. Retrieved 2018-09-20, from http://www . atmos-chem-phys .net/10/7017/2010/ doi: 10.5194/acp-10-7017-2010

Leriche, M., Pinty, J.-P., Mari, C., \& Gazen, D. (2013, August). A cloud chemistry module for the 3-D cloud-resolving mesoscale model Meso-NH with application to idealized cases. Geoscientific Model Development, 6(4), 1275-1298. Retrieved 2018-09-20, from https://www.geosci-model-dev.net/6/1275/2013/ doi: $\quad$ 4/gmd-6-1275-2013

Loughlin, S. C., Sparks, S., Brown, S. K., Jenkins, S. F., \& Vye-Brown, C. (Eds.). (2015). Global Volcanic Hazards and Risk. Cambridge: Cambridge University Press. Retrieved 2019-05-28, from https ://www. cambridge.org/ core/product/identifier/9781316276273/type/book_doi: 10.1017/ CBO9781316276273

Lunet, T., Lac, C., Auguste, F., Visentin, F., Masson, V., \& Escobar, J. $\quad$ (2017, September). $\quad$ Combination of WENO and Explicit RungeKutta Methods for Wind Transport in the Meso-NH Model. Monthly Weather Review, 145(9), 3817-3838. Retrieved 2018-09-20, from http://journals.ametsoc.org/doi/ WR-D-16-0343.1 doi: 10.1175/MWR-D-16-0343.1

Maattanen, A., Merikanto, J., Henschel, H., Duplissy, J., Makkonen, R., Ortega, I. K., \& Vehkamki, H. (2018, January). New Parameterizations for Neutral and Ion-Induced Sulfuric Acid-Water Particle Formation in Nucleation and Kinetic Regimes. Journal of Geophysical Research: Atmospheres, 123(2), 1269-1296. Retrieved 2018-09-20, from http://doi.wiley.com/10.1002/ 2017 JD027429 doi: 10.1002/2017JD027429

Madronich, S., \& Flocke, S. (1999). The Role of Solar Radiation in Atmospheric Chemistry. In P. Boule (Ed.), Environmental Photochemistry (pp. 1-26). Berlin, Heidelberg: Springer Berlin Heidelberg. Retrieved from https://doi.org/10.1007/978-3-540-69044-3\_1 doi: 10.1007/ 978-3-540-69044-3\_1

Masson, V. (2000, March). A Physically-Based Scheme For The Urban Energy Budget In Atmospheric Models. Boundary-Layer Meteorology, 94 (3), 357397. Retrieved 2018-09-18, from http://link.springer.com/10.1023/A: 1002463829265 doi: $10.1023 / \mathrm{A}: 1002463829265$

Mather, T. A. (2015, October). Volcanoes and the environment: Lessons for understanding Earth's past and future from studies of present-day volcanic emissions. Journal of Volcanology and Geothermal Research, 304, 160-179. Retrieved 2018-10-31, from https://linkinghub.elsevier.com/retrieve/ 027315002723 doi: 10.1016/j.jvolgeores.2015.08.016

Mather, T. A., McCabe, J. R., Rai, V. K., Thiemens, M. H., Pyle, D. M., Heaton, T. H. E., .. Fern, G. R. (2006). Oxygen and sulfur isotopic composition of volcanic sulfate aerosol at the point of emission. Journal of Geophysical Research, 111 (D18). Retrieved 2019-01-29, from http://doi.wiley.com/ 005JD006584 doi: 10.1029/2005JD006584

Mather, T. A., Pyle, D. M., \& Oppenheimer, C. (2003). Tropospheric volcanic aerosol. In A. Robock \& C. Oppenheimer (Eds.), Geophysical Monograph Series (Vol. 139, pp. 189-212). Washington, D. C.: American Geophysical Union. Retrieved 2019-04-04, from http://doi.wiley.com/10.1029/139GM12 doi: 10 $.1029 / 139$ GM12

Middleton, P., \& Kiang, C. (1978, January). A kinetic aerosol model for the formation and growth of secondary sulfuric acid particles. Journal of 


\section{Accepted Article}

Aerosol Science, 9(4), 359-385. Retrieved 2019-08-22, from https://

linkinghub.elsevier.com/retrieve/pii/0021850278900381 doi: 21-8502(78)90038-1

Mlawer, E. J., Taubman, S. J., Brown, P. D., Iacono, M. J., \& Clough, S. A. (1997, July). Radiative transfer for inhomogeneous atmospheres: RRTM, a validated correlated-k model for the longwave. Journal of Geophysical Research: Atmospheres, 102(D14), 16663-16682. Retrieved 2018-09-18, from http://doi.wiley.com/10.1029/97JD00237 doi: 10.1029/97JD00237

Noilhan, J., \& Planton, S. (1989, March). A Simple Parameterization of Land Surface Processes for Meteorological Models. Monthly Weather Review, 117(3), 536-549. Retrieved 2018-09-18, from http://journals.ametsoc.org/doi/ abs/10.1175/1520-0493\%281989\%29117\%3C0536\%3AASPOLS\%3E2. 0. CO\%3B2 doi: $\quad 5 / 1520-0493(1989) 117\langle 0536$ :ASPOLS $\rangle 2.0 . \mathrm{CO} ; 2$

Oppenheimer, C., Fischer, T., \& Scaillet, B. (2014). Volcanic Degassing: Process and Impact. In Treatise on Geochemistry (pp. 111-179). Elsevier. Retrieved 2019-05-28, from https://linkinghub.elsevier.com/retrieve/pii/ 59757003041 doi: 10.1016/B978-0-08-095975-7.00304-1

Pinty, J.-P., \& Jabouille, P. ～(1998). ～A mixed-phase cloud parameterization for use in a mesoscale non-hydrostatic model: simulations of a squall line and of orographic precipitation. In Amer. Meteor. soc. (Ed.), Proc. Conf. of Cloud Physics (pp. 217 -220). Everett, WA, USA. Retrieved from http://mesonh.aero.obs-mip.fr/mesonh/dir_publication/ pinty_jabouille_ams_ccp1998.pdf

Quaas, J., \& Boucher, O. (2005, September). Constraining the first aerosol indirect radiative forcing in the LMDZ GCM using POLDER and MODIS satellite data: CONSTRAINING THE AEROSOL INDIRECT EFFECT. Geophysical Research Letters, 32(17). Retrieved 2018-10-30, from http://doi.wiley.com/ 005GL023850 doi: 10.1029/2005GL023850

Queier, M., Burton, M., Theys, N., Pardini, F., Salerno, G., Caltabiano, T., ... Kazahaya, R. (2019, December). TROPOMI enables high resolution SO2 flux observations from Mt. Etna, Italy, and beyond. Scientific Reports, 9(1), 957. Retrieved 2019-05-28, from http://www.nature.com/articles/ s41598-018-37807-w doi: 10.1038/s41598-018-37807-w

Randles, C. A., Colarco, P. R., \& da Silva, A. (2013, January). Direct and semidirect aerosol effects in the NASA GEOS-5 AGCM: aerosol-climate interactions due to prognostic versus prescribed aerosols: AEROSOL-CLIMATE COUPLING IN NASA GEOS-5 AGCM. Journal of Geophysical Research: Atmospheres, 118(1), 149-169. Retrieved 2018-10-30, from http:// doi.wiley.com/10.1029/2012JD018388 doi: 10.1029/2012JD018388

Roberts, T., Vignelles, D., Liuzzo, M., Giudice, G., Aiuppa, A., Coltelli, M., ... Renard, J.-B. (2018, February). The primary volcanic aerosol emission from Mt Etna: Size-resolved particles with SO2 and role in plume reactive halogen chemistry. Geochimica et Cosmochimica Acta, 222, 74-93. Retrieved 2019-01-29, from https://linkinghub.elsevier.com/retrieve/pii/ S0016703717306294 doi: 10.1016/j.gca.2017.09.040

Robock, A. (2000, May). Volcanic eruptions and climate. Reviews of Geophysics, 38(2), 191-219. Retrieved 2018-09-27, from http://doi.wiley.com/10.1029/ 1998RG000054 doi: 10.1029/1998RG000054

Robock, A., \& Oppenheimer, C. (Eds.). (2003). Volcanism and the Earth's Atmosphere (Vol. 139). Washington, D. C.: American Geophysical Union. Retrieved 2019-05-28, from http://doi.wiley.com/10.1029/GM139 doi: 10.1029/GM139

Sahyoun, M., Freney, E., Brito, J., Duplissy, J., Gouhier, M., Colomb, A., ... Sellegri, K. (2019, March). Evidence of new particle formation within Etna and Stromboli volcanic plumes and its parameterization from airborne insitu mea- 
surements. Journal of Geophysical Research: Atmospheres, 2018JD028882. Retrieved 2019-04-10, from https://onlinelibrary.wiley.com/doi/abs/ 018JD028882 doi: 10.1029/2018JD028882

Schmidt, A., Carslaw, K. S., Mann, G. W., Rap, A., Pringle, K. J., Spracklen, D. V., ... Forster, P. M. (2012, August). Importance of tropospheric volcanic aerosol for indirect radiative forcing of climate. Atmospheric Chemistry and Physics, 12(16), 7321-7339. Retrieved 2019-01-29, from https:// www. atmos-chem-phys.net/12/7321/2012/ doi: 10.5194/acp-12-7321-2012

Schmidt, A., Witham, C. S., Theys, N., Richards, N. A. D., Thordarson, T., Szpek, K., ... Carslaw, K. S. (2014, December). Assessing hazards to aviation from sulfur dioxide emitted by explosive Icelandic eruptions. Journal of Geophysical Research: Atmospheres, 119(24), 14,180-14,196. Retrieved 2019-01-29, from http://doi.wiley.com/10.1002/2014JD022070 doi: 14JD022070

Schumann, U. (Ed.). (2012). Atmospheric Physics. Berlin, Heidelberg: Springer Berlin Heidelberg. Retrieved 2019-04-04, from http://link. springer.com/10 -3-642-30183-4 doi: 10.1007/978-3-642-30183-4

Seinfeld, S. P., J.H. (2006). Atmospheric Chemistry and Physics: From Air Pollution to Climate Change. (2nd Edition ed.). New York: John Wiley \& Sons.

Sellitto, P., Zanetel, C., di Sarra, A., Salerno, G., Tapparo, A., Meloni, D., ... Legras, B. (2017, January). The impact of Mount Etna sulfur emissions on the atmospheric composition and aerosol properties in the central Mediterranean: A statistical analysis over the period 20002013 based on observations and Lagrangian modelling. Atmospheric Environment, 148, 77-88. Retrieved 2019-01-28, from https://linkinghub.elsevier.com/retrieve/pii/ S1352231016308391 doi: 10.1016/j.atmosenv.2016.10.032

Stenchikov, G. L., Kirchner, I., Robock, A., Graf, H.-F., Antua, J. C., Grainger, R. G., .. Thomason, L. (1998, June). Radiative forcing from the 1991 Mount Pinatubo volcanic eruption. Journal of Geophysical Research: Atmospheres, 103(D12), 13837-13857. Retrieved 2019-04-29, from http://doi.wiley.com/ 10.1029/98JD00693 doi: 10.1029/98JD00693

Theys, N., Hedelt, P., De Smedt, I., Lerot, C., Yu, H., Vlietinck, J., .. Van Roozendael, M. (2019, December). Global monitoring of volcanic SO2 degassing with unprecedented resolution from TROPOMI onboard Sentinel5 Precursor. Scientific Reports, 9(1), 2643. Retrieved 2019-05-28, from http://www.nature.com/articles/s41598-019-39279-y doi: 10.1038/ s41598-019-39279-y

Tulet, P. (2005). ORILAM, a three-moment lognormal aerosol scheme for mesoscale atmospheric model: Online coupling into the Meso-NH-C model and validation on the Escompte campaign. Journal of Geophysical Research, 110(D18). Retrieved 2018-09-18, from http://doi .wiley.com/10.1029/2004JD005716 doi: $\quad$ 9/2004JD005716

Tulet, P., Di Muro, A., Colomb, A., Denjean, C., Duflot, V., Arellano, S., ... Villeneuve, N. (2017, April). First results of the Piton de la Fournaise STRAP 2015 experiment: multidisciplinary tracking of a volcanic gas and aerosol plume. Atmospheric Chemistry and Physics, 17(8), 5355-5378. Retrieved 2018-08-06, from https://www . atmos-chem-phys.net/17/5355/2017/ doi: p-17-5355-2017

Tulet, P., \& Villeneuve, N. (2011, May). Large scale modeling of the transport, chemical transformation and mass budget of the sulfur emitted during the April 2007 eruption of Piton de la Fournaise. Atmospheric Chemistry and Physics, 11(9), 4533-4546. Retrieved 2019-01-29, from http:// www. atmos-chem-phys.net/11/4533/2011/ doi: 10.5194/acp-11-4533-2011

van der Werf, G. R., Randerson, J. T., Giglio, L., Collatz, G. J., Mu, M., Kasibhatla, P. S., .. van Leeuwen, T. T. (2010, December). Global fire emissions 


\section{Accepted Article}

and the contribution of deforestation, savanna, forest, agricultural, and peat fires (19972009). Atmospheric Chemistry and Physics, 10(23), 11707-11735. Retrieved 2018-09-20, from http://www.atmos-chem-phys.net/10/11707/ 2010/ doi: 10.5194/acp-10-11707-2010

Voldoire, A., Decharme, B., Pianezze, J., Lebeaupin Brossier, C., Sevault, F., Seyfried, L., ... Riette, S. (2017, November). SURFEX v8.0 interface with OASIS3-MCT to couple atmosphere with hydrology, ocean, waves and seaice models, from coastal to global scales. Geoscientific Model Development, 10(11), 4207-4227. Retrieved 2018-08-06, from https://www.geosci-model 10/4207/2017/ doi: 10.5194/gmd-10-4207-2017

Voldoire, A., Sanchez-Gomez, E., Salas y Mlia, D., Decharme, B., Cassou, C., Snsi, S., .. Chauvin, F. (2013, May). The CNRM-CM5.1 global climate model: description and basic evaluation. Climate Dynamics, 40(9-10), 20912121. Retrieved 2018-10-30, from http://link. springer.com/10.1007/ s00382-011-1259-y doi: 10.1007/s00382-011-1259-y

Weber, R. J., McMurry, P. H., Eisele, F. L., \& Tanner, D. J. (1995, June). Measurement of Expected Nucleation Precursor Species and 3500-nm Diameter Particles at Mauna Loa Observatory, Hawaii. Journal of the Atmospheric Sciences, 52(12), 2242-2257. Retrieved 2018-09-27, from http://journals.ametsoc .org/doi/abs/10.1175/1520-0469\%281995\%29052\%3C2242\%3AMOENPS\%3E2.0 .CO\%3B2 doi: 10.1175/1520-0469(1995)052〈2242:MOENPS $\rangle 2.0 . C O ; 2$

Weber, R. J., McMurry, P. H., Mauldin, R. L., Tanner, D. J., Eisele, F. L., Clarke, A. D., \& Kapustin, V. N. $\quad$ (1999, February). New Particle Formation in the Remote Troposphere: A Comparison of Observations at Various Sites. Geophysical Research Letters, 26(3), 307-310. Retrieved 2018-09-27, from http://doi.wiley.com/10.1029/1998GL900308 doi: 98GL900308

Weigel, R., Hermann, M., Curtius, J., Voigt, C., Walter, S., Bttger, T., ... Borrmann, S. (2009, June). Experimental characterization of the COndensation PArticle counting System for high altitude aircraft-borne applica-

tion. Atmospheric Measurement Techniques, 2(1), 243-258. Retrieved 2019-03-19, from http://www . atmos-meas-tech.net/2/243/2009/ doi: 10.5194/amt-2-243-2009

Whitby, E. R., \& McMurry, P. H. (1997, January). Modal Aerosol Dynamics Modeling. Aerosol Science and Technology, 27(6), 673-688. Retrieved 2018-09-18, from http://www.tandfonline.com/doi/abs/10.1080/02786829708965504 doi: $\quad$ 0/02786829708965504 